\title{
Ecophysiology and Comparative Genomics of Nitrosomonas mobilis Ms1 Isolated from Autotrophic Nitrifying Granules of Wastewater Treatment Bioreactor
}

\author{
Soe Myat Thandar ${ }^{1,2}$, Norisuke Ushiki ${ }^{1}$, Hirotsugu Fujitani ${ }^{1}$, Yuji Sekiguchi ${ }^{3}$ and \\ Satoshi Tsuneda ${ }^{1 *}$
}

${ }^{1}$ Tsuneda Laboratory, Department of Life Science and Medical Bioscience, Waseda University, Tokyo, Japan, ${ }^{2}$ Department of Biotechnology, Mandalay Technological University, Ministry of Education, Mandalay, Myanmar, ${ }^{3}$ Advanced Biomeasurements Research Group, Biomedical Research Institute, National Institute of Advanced Industrial Science and Technology, Ibaraki, Japan

OPEN ACCESS

Edited by: Martin G. Klotz,

Queens College (CUNY), USA

Reviewed by:

Andreas Schramm,

Aarhus University, Denmark Hidetoshi Urakawa,

Florida Gulf Coast University, USA

*Correspondence:

Satoshi Tsuneda

stsuneda@waseda.jp

Specialty section: This article was submitted to

Evolutionary and Genomic Microbiology,

a section of the journal

Frontiers in Microbiology

Received: 20 August 2016 Accepted: 07 November 2016 Published: 22 November 2016

Citation:

Thandar SM, Ushiki N, Fujitani H, Sekiguchi Y and Tsuneda S (2016) Ecophysiology and Comparative Genomics of Nitrosomonas mobilis Ms1 Isolated from Autotrophic Nitrifying Granules of Wastewater Treatment Bioreactor.

Front. Microbiol. 7:1869. doi: 10.3389/fmicb.2016.01869
Ammonia-oxidizing bacteria (AOB), which oxidize ammonia to nitrite in the first step of nitrification, play an important role in biological wastewater treatment systems. Nitrosomonas mobilis is an important and dominant $\mathrm{AOB}$ in various wastewater treatment systems. However, the detailed physiological and genomic properties of N. mobilis have not been thoroughly investigated because of limited success isolating pure cultures. This study investigated the key physiological characteristics of N. mobilis Ms1, which was previously isolated into pure culture from the nitrifying granules of wastewater treatment bioreactor. The pure culture of $N$. mobilis Ms1 was cultivated in liquid mineral medium with $30 \mathrm{mg}-\mathrm{N} \mathrm{L}^{-1}(2.14 \mathrm{mM})$ of ammonium at room temperature under dark conditions. The optimum growth of $\mathrm{N}$. mobilis $\mathrm{Ms} 1$ occurred at $27^{\circ} \mathrm{C}$ and $\mathrm{pH}$ 8 , with a maximum growth rate of $0.05-0.07 \mathrm{~h}^{-1}$, which corresponded to a generation time of 10-14 $\mathrm{h}$. The half saturation constant for ammonium uptake rate and the maximum ammonium uptake rate of $\mathrm{N}$. mobilis $\mathrm{Ms} 1$ were $30.70 \pm 0.51 \mu \mathrm{M} \mathrm{NH}_{4}{ }^{+}$and $0.01 \pm 0.002$ pmol NH$_{4}{ }^{+}$cells ${ }^{-1} \mathrm{~h}^{-1}$, respectively. N. mobilis Ms 1 had higher ammonia oxidation activity than $N$. europaea in this study. The oxygen uptake activity kinetics of N. mobilis Ms1 were $K_{\mathrm{m}\left(\mathrm{O}_{2}\right)}=21.74 \pm 4.01 \mu \mathrm{M} \mathrm{O}_{2}$ and $V_{\max \left(\mathrm{O}_{2}\right)}=0.06 \pm 0.02 \mathrm{pmol}$ $\mathrm{O}_{2}$ cells ${ }^{-1} \mathrm{~h}^{-1}$. Ms1 grew well at ammonium and $\mathrm{NaCl}$ concentrations of up to 100 and $500 \mathrm{mM}$, respectively. The nitrite tolerance of $\mathrm{N}$. mobilis Ms1 was extremely high (up to $300 \mathrm{mM}$ ) compared to AOB previously isolated from activated sludge and wastewater treatment plants. The average nucleotide identity between the genomes of $N$. mobilis Ms1 and other Nitrosomonas species indicated that N. mobilis Ms1 was distantly related to other Nitrosomonas species. The organization of the genes encoding protein inventory involved in ammonia oxidation and nitrifier denitrification processes were different from other Nitrosomonas species. The current study provides a needed physiological and genomic characterization of N. mobilis-like bacteria and a better understanding of their ecophysiological properties, enabling comparison of these bacteria with other $\mathrm{AOB}$ in wastewater treatment systems and natural ecosystems.

Keywords: nitrification, ammonia oxidation, wastewater, kinetics, Nitrosomonas, physiological characteristics, genomic properties 


\section{INTRODUCTION}

Nitrification, the oxidation process of ammonia and nitrite followed by denitrification, is an important process in the nitrogen cycle of natural ecosystems and in biological wastewater treatment systems. This process is mainly performed by two groups of nitrifying microbes, ammonia-oxidizing bacteria and archaea (AOB and $\mathrm{AOA}$ ), which convert ammonia $\left(\mathrm{NH}_{3}\right)$ to nitrite $\left(\mathrm{NO}_{2}{ }^{-}\right)$in two steps, and nitrite-oxidizing bacteria (NOB) that oxidize the nitrite $\left(\mathrm{NO}_{2}{ }^{-}\right)$to nitrate $\left(\mathrm{NO}_{3}{ }^{-}\right)$. Recently, some species belonging to lineage II of the genus Nitrospira in the NOB group have been reported as complete ammonia oxidizing bacteria (comammox) that perform the complete nitrification of ammonia to nitrate (Daims et al., 2015; van Kessel et al., 2015).

Because of the important role of nitrification in both the natural environment and wastewater treatment systems, researchers have long been trying to understand the ecophysiology of nitrifying microorganisms. Studies on nitrifying microbes in wastewater treatment systems and the natural environment using molecular methods have indicated that Nitrosomonas species are the main AOB populations in wastewater treatment bioreactors (Tsuneda et al., 2003; Chen and Wong, 2004; Mota et al., 2005; Wells et al., 2009), as well as in diverse natural environments including freshwater, coastal and brackish water regions (Stehr et al., 1995; Zhang et al., 2015). Among Nitrosomonas species, Nitrosomonas europaea/Nitrosomonas mobilis cluster 7 was dominant in wastewater treatment bioreactors loaded with high concentrations of ammonia and nitrite, whereas Nitrosomonas oligotropha cluster 6a was dominant in systems with a lower ammonia environment (Suwa et al., 1994, 1997; Bollmann and Laanbroek, 2001; Limpiyakorn et al., 2005, 2007; Tan et al., 2008). Nitrosomonas mobilis-like bacteria were codominant with $N$. europaea-eutropha- and N. oligotropha-like bacteria in the biofilm's microbial populations in wastewater treatment bioreactors (Gieseke et al., 2003). In a study of nitrifying granules, $N$. mobilis-like bacteria were predominant from the nascent stage into maturity where $N$. europaea- and $N$. oligotropha-like bacteria were also present (Matsumoto et al., 2010). N. mobilis was also dominant in various wastewater treatment bioreactors (Juretschko et al., 1998; Chen and Wong, 2004; Mota et al., 2005). Because of this environmental distribution, N. mobilis has received a great deal of attention in the field of wastewater treatment.

The first isolation of Nitrosococcus mobilis from brackish water had been reported by Koops et al. (1976). It was later proposed that Nitrosococcus mobilis should be moved into the genus Nitrosomonas (Head et al., 1993). The original isolates (strains $\mathrm{Nc} 2^{\mathrm{T}}, \mathrm{Nc} 3, \mathrm{Nc} 8$ ) of $\mathrm{N}$. mobilis were from brackish water, but a few environmental clones and pure strains ( $\mathrm{Nm}$ 93, Nm104, Nm107) of N. mobilis have also been isolated from activated sludge samples (Koops and Harms, 1985; Juretschko et al., 1998; Purkhold et al., 2000). Studies of pure cultures and environmental clones of $N$. mobilis have been included in some phylogenetic analyses (Koops and Harms, 1985; Head et al., 1993; Pommerening-Roser et al., 1996; Juretschko et al., 1998; Purkhold et al., 2000; Cantera and Stein, 2007) and investigations of gene expression response to copper and zinc (Radniecki and Ely, 2008, 2011). According to Campbell et al. (2011), Nitrosococcus mobilis was published as Nitrosomonas mobilis with the type strain Nc2. However, to date, no representative strains of $N$. mobilis suitable for examination of their physiological and genomic characteristics have been reported and detailed information regarding the physiological and genomic characterization of $N$. mobilis is still lacking because of the limited success in isolating it into pure cultures.

Recently, the pure culture of Nitrosomonas mobilis Ms1 has been successfully isolated from the autotrophic nitrifying granules by selective isolation using a cell-sorting system (Fujitani et al., 2015). These nitrifying granules were produced in the aerobic upflow fluidized bed reactor to treat inorganic wastewater and exhibited an effective ammonia removal rate (Tsuneda et al., 2003). During the granule formation, Nitrosomonas species and Nitrosomonas mobilis act as an important and dominant AOB population (Tsuneda et al., 2003; Matsumoto et al., 2010). To accomplish an ecophysiological study of $N$. mobilis and related Nitrosomonas species, in this study we investigated key physiological characteristics such as temperature and $\mathrm{pH}$ ranges, growth rate, $\mathrm{NaCl}$ tolerance, ammonium and oxygen uptakes activity kinetics, ammonium substrate inhibition and nitrite tolerance of N. mobilis Ms1. In addition, genome sequencing and annotation of the genes were conducted. The genes encoding proteins involved in ammonia oxidation and nitrogen oxide metabolism were also identified. This study is the first physiological and genomic characterization of Nitrosomonas mobilis and provides important information regarding $N$. mobilis-like strains.

\section{MATERIALS AND METHODS}

\section{Cell Cultures, Media, and Cultivation}

Nitrosomonas mobilis Ms1 isolated from nitrifying granules (Fujitani et al., 2015) was kept in liquid culture of mineral medium containing $30 \mathrm{mg}-\mathrm{N} \mathrm{L}^{-1}$ of ammonium substrate $\left(\mathrm{NH}_{4} \mathrm{Cl}\right)$ with the following components per liter of distilled water: $\mathrm{NaCl}(0.116 \mathrm{~g}), \mathrm{MgSO}_{4} \cdot 7 \mathrm{H}_{2} \mathrm{O}(0.4 \mathrm{~g}), \mathrm{CaCl}_{2} \cdot 2 \mathrm{H}_{2} \mathrm{O}$ (0.073 g), $\mathrm{KCl}(0.038 \mathrm{~g}), \mathrm{KH}_{2} \mathrm{PO}_{4}(0.034 \mathrm{~g}), \mathrm{FeCl}_{2}(0.002 \mathrm{~g})$, EDTA (0.0043 g), $\quad \mathrm{MnCl}_{2} \cdot 4 \mathrm{H}_{2} \mathrm{O}(0.1 \mathrm{mg}), \quad \mathrm{CoCl}_{2} \cdot 6 \mathrm{H}_{2} \mathrm{O}$ (0.024 mg), $\mathrm{NiCl}_{2} \cdot 6 \mathrm{H}_{2} \mathrm{O}(0.024 \mathrm{mg}), \mathrm{CuCl}_{2} \cdot 2 \mathrm{H}_{2} \mathrm{O}(0.017 \mathrm{mg})$, $\mathrm{ZnCl}_{2}(0.068 \mathrm{mg}), \quad \mathrm{Na}_{2} \mathrm{WO}_{4} \cdot 2 \mathrm{H}_{2} \mathrm{O}(0.033 \mathrm{mg}), \quad \mathrm{Na}_{2} \mathrm{MoO}_{4}$ (0.024 mg), and $\mathrm{H}_{3} \mathrm{BO}_{3}(0.062 \mathrm{mg})$. The $\mathrm{pH}$ of the culture media was adjusted to 8.0 by $\mathrm{NaHCO}_{3}\left(0.84 \mathrm{~g} \mathrm{~L}^{-1}\right)$, and phenol red $(0.4 \mathrm{w} / \mathrm{v} \%)$ was used as the $\mathrm{pH}$ indicator. The cultures were incubated under static and dark conditions at room temperature. For physiological and kinetics studies, mineral media with different ammonium concentrations was used and phenol red was omitted. To determine the effect of $\mathrm{NaCl}$ concentration, mineral media without $\mathrm{NaCl}$ was used. Nitrosomonas europaea Winogradsky 1892 (NBRC 14298) was purchased from the Biological Resource Center (NBRC), National Institute of Technology and Evaluation (NITE). The HEPES medium 829 as described in the manual NBRC No. 14298 was used as the growth medium in this study. For the activity experiment, 
media with separately prepared different concentrations of ammonium substrate $\left[\left(\mathrm{NH}_{4}\right)_{2} \mathrm{SO}_{4}\right]$ was used. The stock cultures of $N$. mobilis Ms1 and N. europaea were periodically checked for their culture conditions $(\mathrm{pH}$, ammonium and produced nitrite concentrations), cell growth and morphologies, and transferred into fresh culture media when the nitrite concentrations in media reached approximately $200 \mathrm{mg}-\mathrm{N} \mathrm{L}^{-1}$.

\section{Fluorescence Microscopy}

The growth and morphology of the cell cultures during the experiments were observed by fluorescence microscopy. Briefly, $10 \mu \mathrm{L}$ cell samples were applied to each well of 12 -well glass slides and allowed to dry. The samples were then dried and stained with SYTOX Green nucleic acid stain (Life Technologies, Molecular Probes, Eugene, OR, USA) and observed under a fluorescence microscope (Zeiss Axioskop 2plus, lens Zeiss Plan-APOCHROMAT $100 \times / 1.4$ oil, Carl Zeiss, Oberkochen, Germany). To count the cell numbers, $1 \mathrm{~mL}$ of culture samples were sonicated at intensity of 4 for $1 \mathrm{~min}$ (Sonifier II model, Branson, Danbury, CT, USA) and heated at $95^{\circ} \mathrm{C}$ for $10 \mathrm{~min}$, after which, $1 \mu \mathrm{L}$ cell samples were applied to each well of the 12 well glass slides. The cell numbers were quantitatively analyzed from each well using a microscopic direct counting method. The mean cell numbers were determined from triplicate wells for each sample.

\section{Measurement of Ammonium and Nitrite Concentrations}

The samples for measurement were collected by filtration through a $0.22 \mu \mathrm{m}$ Micropore filter (Millex, Merck Millipore, Darmstadt, Germany), after which the ammonium and nitrite concentrations of collected samples were measured colorimetrically with a modified indophenol reaction (Kandeler and Gerber, 1988) at an absorbance wavelength of $630 \mathrm{~nm}$ and Griess Reagent (Griess-Romijn van Eck, 1966) at an absorbance wavelength of $550 \mathrm{~nm}$, respectively, using a Powerscan HT microplate spectrophotometer (BioTek, Winooski, VT, USA).

\section{Effect of Temperature, $\mathrm{pH}$ and $\mathrm{NaCl}$ Concentration on the Growth of Ms1}

Batch cultures experiments were conducted to investigate the effects of temperature, $\mathrm{pH}$ and $\mathrm{NaCl}$ concentrations on the growth of $N$. mobilis Ms1. The culture sample was concentrated by centrifugation at $4,800 \times g$ and $23^{\circ} \mathrm{C}$ for $30 \mathrm{~min}$. The sample pellet was then mixed with fresh mineral medium containing $30 \mathrm{mg}-\mathrm{N} \mathrm{L}^{-1}(2.14 \mathrm{mM})$ initial ammonium substrate $\left(\mathrm{NH}_{4} \mathrm{Cl}\right)$ and subjected to weak sonication. To investigate the effect of $\mathrm{NaCl}$ concentration, fresh mineral media containing different $\mathrm{NaCl}$ concentrations $(0,50,100,250,500,750$, and 1,000 mM) were used. To investigate the effects of $\mathrm{pH}$, the culture media were adjusted to a $\mathrm{pH}$ of $4,5,6,7,8,9,11$, or 13 by $\mathrm{NaOH}$ and $\mathrm{HCl}$, then mixed with the sample pellet and subjected to weak sonication. Next, the cultures were incubated in rotatory shaker incubators at different temperatures $\left(7-47^{\circ} \mathrm{C}, \mathrm{pH} 8.0\right), \mathrm{pHs}(\mathrm{pH}$ $4-13,27^{\circ} \mathrm{C}$ ) and $\mathrm{NaCl}$ concentrations $\left(\mathrm{NaCl} 0-1,000 \mathrm{mM}, 27^{\circ} \mathrm{C}\right.$, $\mathrm{pH} 8.0)$ for $24 \mathrm{~h}$. Aliquots of samples (1-2 mL) were taken out at the start of the incubation period $(0 \mathrm{~h}), 1 \mathrm{~h}$ (for the temperature experiments because the culture samples were assumed to have adapted to each temperature at this point) and the end of the incubation $(24 \mathrm{~h})$, then collected by filtration through a $0.22 \mu \mathrm{m}$ Micropore filter (Millex). The growth of N. mobilis Ms1 was measured based on the nitrite concentrations of the collected samples. All experiments were conducted in triplicate.

\section{Maximum Specific Growth Rate ( $\left.\mu_{\max }\right)$}

The growth rate of $N$. mobilis Ms1 was studied by batch culture of $5 \mathrm{~mL}$ aliquots from pure cultures of $N$. mobilis Ms1 with $100 \mathrm{mg}-\mathrm{N} \mathrm{L}^{-1}(7.14 \mathrm{mM})$ initial ammonium substrate in $100 \mathrm{~mL}$ fresh mineral media using $500 \mathrm{~mL}$ experimental flasks. The initial $\mathrm{pH}$ value of the batch cultures was 8.0 and the initial cell concentrations were approximately $1.64 \times 10^{4}-3.73 \times 10^{5}$ cells $\mathrm{mL}^{-1}$. The cultures were incubated at $27^{\circ} \mathrm{C}$ on a rotatory shaker incubator for 1 week until all ammonium was consumed. During the incubation period, the $\mathrm{pH}$ of the culture was kept constant at around 8.0 by adding sterile $\mathrm{NaHCO}_{3}$. The aliquots of samples $(1-2 \mathrm{~mL})$ were taken out daily at the same time from the start until the end of the incubation period and collected by filtering through a $0.22 \mu \mathrm{m}$ Micropore filter (Millex) to determine the ammonium and nitrite concentrations. The cell numbers were also determined by direct microscopic counting with Sytox green staining. The specific growth rate $(\mu)$ and generation time (g) were then calculated using the following equations:

$$
\begin{gathered}
\mu=\frac{\operatorname{Ln}\left(\mathrm{X}_{2}-\mathrm{X}_{1}\right)}{\left(\mathrm{t}_{2}-\mathrm{t}_{1}\right)} \\
g=\frac{\operatorname{Ln}(2)}{\mu}
\end{gathered}
$$

where $\mathrm{X}$ is the number of cells and $\mathrm{t}$ is the time (Belser and Schmidt, 1980). All experiments were conducted in duplicate.

\section{Activity Kinetics}

The activity kinetics of $N$. mobilis Ms1 were investigated by measuring the ammonium and oxygen uptake activities. To determine the ammonium uptakes, short-term incubation in a batch culture was conducted. The culture sample of $N$. mobilis Ms1 was concentrated by centrifugation at $4,800 \times g$ and $23^{\circ} \mathrm{C}$ for $30 \mathrm{~min}$. The sample pellet was mixed with $100 \mathrm{~mL}$ of fresh mineral medium containing $7.0 \mathrm{mg}-\mathrm{N} \mathrm{L}^{-1}(500 \mu \mathrm{M})$ of ammonium and subjected to weak sonication. The cell concentrations of the experimental cultures were approximately $1.31 \times 10^{7}-2.82 \times 10^{7}$ cells $\mathrm{mL}^{-1}$. The ammonium uptake activity kinetics of $N$. europaea were also studied for comparison with those of $N$. mobilis Ms1. The culture sample of $N$. europaea was concentrated as in N. mobilis Ms1 and mixed with $100 \mathrm{~mL}$ fresh mineral medium containing $5.0 \mathrm{mg}-\mathrm{N} \mathrm{L}^{-1}(357.14 \mu \mathrm{M})$. The $\mathrm{pH}$ of the media was then adjusted to around 8.0 by $\mathrm{NaHCO}_{3}$. Next, samples were incubated at $27^{\circ} \mathrm{C}$ in a rotatory shaker incubator for about 3-6 h until all ammonium was consumed, during which time aliquots of samples (1-2 mL) were taken out every $10 \mathrm{~min}$, filtered through a $0.22 \mu \mathrm{m}$ Micropore filter (Millex), and measured for ammonium concentration. The 
cell numbers in the aliquots of the samples collected at $0 \mathrm{~h}$ were also counted. The ammonium concentrations obtained over time and the ammonium uptake rates were fitted to the MichaelisMenten equation, which is as follows:

$$
V=\frac{\left(V_{\left.\max \left(\mathrm{NH}_{4}^{+}\right) \times\left[\mathrm{NH}_{4}^{+}\right]\right)}\right.}{\left(K_{\mathrm{m}\left(\mathrm{NH}_{4}^{+}\right)}+\left[\mathrm{NH}_{4}^{+}\right]\right)}
$$

where $V$ is the ammonium uptake rate, $V_{\max \left(\mathrm{NH}_{4}^{+}\right)}$is the maximum ammonium uptake rate, $K_{\mathrm{m}\left(\mathrm{NH}_{4}^{+}\right)}$is the half saturation constant for ammonium uptake, and $\left[\mathrm{NH}_{4}{ }^{+}\right]$is the ammonium concentration. $V_{\max }\left(\mathrm{NH}_{4}^{+}\right)$was calculated as the ammonium uptake rate per cell concentration. All experiments were conducted in duplicate. The specific affinity for ammonium was calculated using the ratio of kinetics values from ammonium uptake activity (i.e., $\left.V_{\max \left(\mathrm{NH}_{4}^{+}\right)} \times\left[\mathrm{K}_{\mathrm{m}\left(\mathrm{NH}_{4}^{+}\right)}\right]^{-1}\right)$ (Laanbroek and Gerards, 1993).

An $\mathrm{O}_{2}$ microsensor (OX-MR13831, Unisense, Aarhus, Denmark) was used to measure the oxygen uptake of N. mobilis Ms1. The chamber and sensor were assembled in the water bath, and the temperature of the water bath was set to $30^{\circ} \mathrm{C}$, at which time the sensor was calibrated. Next, $2 \mathrm{~mL}$ aliquots from N. mobilis Ms1 culture containing with $2.35 \times 10^{6}-5.20 \times 10^{6}$ cells $\mathrm{mL}^{-1}$ were added into the chamber with a glass-coated magnet stirrer and the $\mathrm{O}_{2}$ sensor was immersed in the sample. When the $\mathrm{O}_{2}$ concentration was stable, measurement of the oxygen levels in the cell culture started. The data (oxygen concentrations over time) obtained by the $\mathrm{O}_{2}$ sensor were analyzed and smoothed using the SigmaPlot software (SigmaPlot 13.0, Systat software GmbH, Erkrath, Germany). Subsamples from the cell culture were used to count the cell numbers by direct microscopy after Sytox green staining. $K_{\mathrm{m}\left(\mathrm{O}_{2}\right)}$ and $V_{\max }\left(\mathrm{O}_{2}\right)$ were calculated from the measured oxygen uptake rate and the counted cell numbers using the Michaelis-Menten equation:

$$
V=\frac{\left(V_{\max \left(\mathrm{O}_{2}\right)} \times\left[\mathrm{O}_{2}\right]\right)}{\left(K_{\mathrm{m}\left(\mathrm{O}_{2}\right)}+\left[\mathrm{O}_{2}\right]\right)}
$$

where $V$ is the oxygen uptake rate, $V_{\max }\left(\mathrm{O}_{2}\right)$ is the maximum oxygen uptake rate, $K_{\mathrm{m}}\left(\mathrm{O}_{2}\right)$ is the half saturation constant for oxygen uptake rate, and $\left[\mathrm{O}_{2}\right]$ is the oxygen concentration. All experiments were conducted in triplicate.

\section{Ammonium and Nitrite Tolerance}

To investigate the ammonium and nitrite tolerance of $N$. mobilis Ms1, batch experiments were conducted using different ammonium and nitrite concentrations. N. mobilis Ms1 was cultivated in $100 \mathrm{~mL}$ of fresh mineral media using $500 \mathrm{~mL}$ flasks containing different initial ammonium concentrations (10, 50, $100,200,300,400$, and $500 \mathrm{mM})$ and nitrite concentrations (0, $5,10,50,100,200,300,400$, and $500 \mathrm{mM}$ ) in which an initial ammonium concentration of $5 \mathrm{mM}$ was contained. The $\mathrm{pH}$ of all media was adjusted to 8.0 by $\mathrm{NaHCO}_{3}$. Cultures were incubated at $27^{\circ} \mathrm{C}$ in a rotatory incubator until all ammonium was consumed. During the experiment, aliquots of samples (1-2 mL) were collected at the start of the incubation period and every other day from 10 to $100 \mathrm{mM}$ ammonium and 0$100 \mathrm{mM}$ nitrite cultures, and every 4th day from 200 to $500 \mathrm{mM}$ ammonium and nitrite cultures by filtering with a $0.22 \mu \mathrm{m}$ Micropore filter (Millex). The initial ammonium concentrations and produced nitrite concentrations of the collected samples were measured colorimetrically by indophenol and Griess Reagent tests, respectively. During the incubation period, the cell growth was observed by Sytox green fluorescence microscopic examination of the collected samples and the $\mathrm{pHs}$ of the media were kept constant at around 8.0 by adding sterile $\mathrm{NaHCO}_{3}$. All experiments were conducted in duplicate.

\section{Genome Sequencing, Assembly and Gene Annotation}

A draft genome sequence of strain Ms1 was performed as follows. Briefly, genomic DNA was extracted from a pure
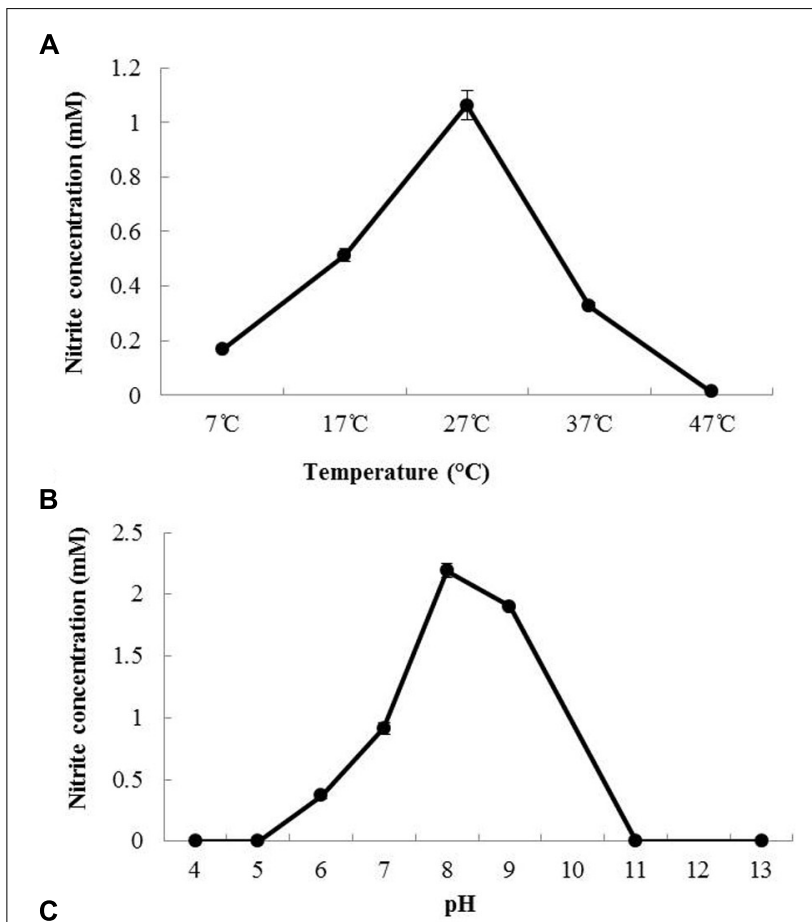

C

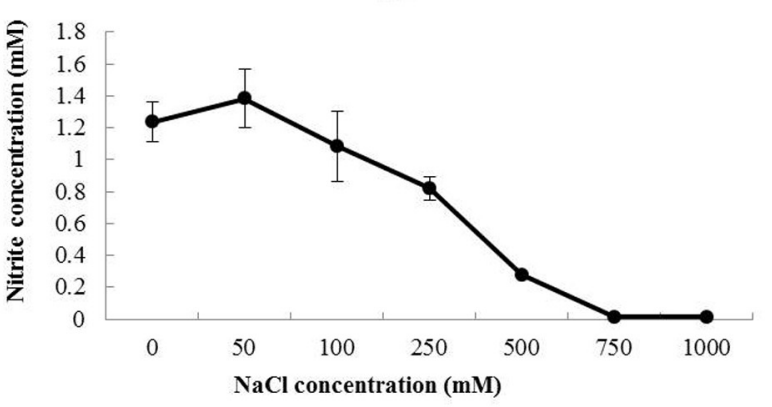

FIGURE 1 | Effect of temperature, $\mathrm{pH}$ and $\mathrm{NaCl}$ concentration on the growth of $\boldsymbol{N}$. mobilis Ms1. The nitrite concentrations of N. mobilis Ms1 after $24 \mathrm{~h}$ of incubation at different temperatures (A), pHs (B), and $\mathrm{NaCl}$ concentrations (C). Bars are the standard errors $(n=3)$. 
TABLE 1 | Physiological characteristics of pure cultures of $\boldsymbol{N}$. mobilis Ms1 and some AOB species.

\begin{tabular}{|c|c|c|c|c|c|c|c|}
\hline \multirow[t]{2}{*}{ Strains } & \multicolumn{4}{|c|}{ N. europaea/N. mobilis lineage, cluster 7} & \multirow{2}{*}{$\begin{array}{c}\text { N. communis } \\
\text { lineage, cluster } 8 \\
\begin{array}{c}\text { Nitrosomonas sp. } \\
\text { strain JPCCT2 }\end{array}\end{array}$} & \multirow{2}{*}{$\begin{array}{c}\begin{array}{c}\text { N. oligotropha } \\
\text { lineage, cluster } \\
6 \mathrm{a}\end{array} \\
\begin{array}{c}\text { Nitrosomonas sp. } \\
\text { strain AL212 }\end{array}\end{array}$} & \multirow{2}{*}{$\begin{array}{c}\begin{array}{c}\text { Unclassified } \\
\text { cluster }\end{array} \\
\begin{array}{c}\text { N. stercoris } \\
\text { KYUHI-S }\end{array}\end{array}$} \\
\hline & N. mobilis Ms1 & 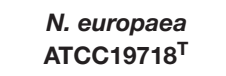 & $\begin{array}{l}\text { N. eutropha } \\
\text { C- } 91^{\top}\end{array}$ & N. mobilis Nc2 ${ }^{\top}$ & & & \\
\hline Temperature range $\left({ }^{\circ} \mathrm{C}\right)$ & $17-37$ & $10-40^{a}$ & NA & $10-30$ & $28-48$ & NA & $20-37$ \\
\hline Optimum temperature $\left({ }^{\circ} \mathrm{C}\right)$ & 27 & $25-29^{a}$ & 30 & $25-30$ & 28 & 25 & 25 \\
\hline $\mathrm{pH}$ range $(-)$ & $7-9$ & NA & NA & $6.8-8.3$ & $4.7-8.3$ & NA & $7-9$ \\
\hline Optimum pH (-) & 8.0 & $7.8-8.2^{\mathrm{a}}$ & $7.5-8.0$ & $7.5-7.8$ & $7.5-8.0$ & 7.2 & 8.0 \\
\hline Growth rate, $\mu_{\max }\left(\mathrm{h}^{-1}\right)$ & $0.06 \pm 0.01$ & $0.05-0.07$ & NA & $0.053-0.058$ & NA & $0.014-0.025^{d}$ & 0.029 \\
\hline Generation time (h) & $10-14$ & $10-14$ & NA & $12-13$ & NA & $28-49^{d}$ & 24 \\
\hline $\mathrm{NaCl}$ requirement & - & - & - & + & - & - & - \\
\hline $\begin{array}{l}\text { Maximum } \mathrm{NaCl} \text { tolerance } \\
(\mathrm{mM})\end{array}$ & 500 & 400 & 400 & 500 & 300 & NA & 400 \\
\hline $\begin{array}{l}\text { Half-saturation constant, } \\
K_{\mathrm{m}\left(\mathrm{NH}_{4}^{+}\right)}\left(\mu \mathrm{M} \mathrm{NH}_{4}^{+}\right)\end{array}$ & $30.70 \pm 0.51$ & $55.43 \pm 4.92^{b}$ & NA & NA & NA & NA & NA \\
\hline $\begin{array}{l}\text { Maximum ammonium } \\
\text { uptake rate per cell, } \\
V_{\max \left(\mathrm{NH}_{4}^{+}\right)}\left(\mathrm{pmol} \mathrm{NH}_{4}{ }^{+}\right. \\
\text {cells } \\
\left.-1 \mathrm{~h}^{-1}\right)\end{array}$ & $0.01 \pm 0.002$ & $0.0009 \pm 0.00003^{b}$ & NA & NA & NA & NA & NA \\
\hline $\begin{array}{l}\text { Half-saturation constant, } \\
K_{\mathrm{m}\left(\mathrm{O}_{2}\right)}\left(\mu \mathrm{M} \mathrm{O}_{2}\right)\end{array}$ & $21.74 \pm 4.01$ & NA & NA & NA & NA & NA & NA \\
\hline $\begin{array}{l}\text { Maximum oxygen uptake } \\
\text { rate per cell, } V_{\max \left(\mathrm{O}_{2}\right)}(\mathrm{pmol} \\
\left.\mathrm{O}_{2} \text { cells }^{-1} \mathrm{~h}^{-1}\right)\end{array}$ & $0.06 \pm 0.02$ & NA & NA & NA & NA & NA & NA \\
\hline $\begin{array}{l}\text { Maximum ammonium } \\
\text { tolerance }(\mathrm{mM})\end{array}$ & 100 & 400 & 600 & 300 & NA & 10.7 & 1000 \\
\hline $\begin{array}{l}\text { Ammonium concentration } \\
\text { in standard growth medium } \\
(\mathrm{mM})\end{array}$ & 2.14 & 10 & 10 & 9.34 & $11.25-15.0$ & 3.57 & 38 \\
\hline Nitrite tolerance (mM) & 300 & $20^{c}$ & 10 & 14.28 & NA & $2.1-5.4^{\mathrm{e}}$ & 200 \\
\hline Origin & Nitrifying granules & Wastewater & Municipal sewage & Brackish water & Activated sludge & Activated sludge & Compost \\
\hline Reference & This study & $\begin{array}{c}\text { Belser and } \\
\text { Schmidt, 1980; } \\
\text { Koops et al., 1991, } \\
\text { 2006; Tokuyama } \\
\text { et al., 1997; Stein } \\
\text { and Arp, 1998; Cua } \\
\text { and Stein, 2011 }\end{array}$ & $\begin{array}{l}\text { Koops et al., 1991, } \\
\text { 2006; Cua and } \\
\text { Stein, } 2011\end{array}$ & $\begin{array}{l}\text { Koops et al., 1976, } \\
1990\end{array}$ & Itoh et al., 2013 & $\begin{array}{l}\text { Suwa et al., 1994, } \\
\text { 1997; Limpiyakorn } \\
\text { et al., } 2007\end{array}$ & $\begin{array}{l}\text { Nakagawa and } \\
\text { Takahashi, } 2015\end{array}$ \\
\hline
\end{tabular}

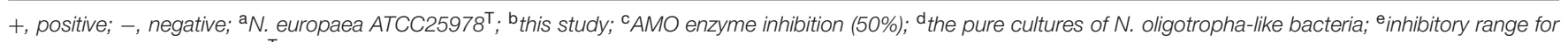
N. oligotropha-like bacteria; 'Type strain; NA, not available.

culture of strain Ms1 by using NucleoSpin ${ }^{\circledR}$ Tissue, a DNA extraction kit (Takara Bio, Otsu, Japan) according to the manufacturer's instructions, and a Nextera XT paired-end (300-1,000 bp) was prepared from the extracted DNA. The library was then sequenced on an Illumina MiSeq instrument with V2 chemistry $(2 \times 250$ bp reads $)$ at an expected coverage of $120 \times$ per genome. Raw sequence reads were merged with SeqPrep with concurrent removal of sequencing adaptors, followed by quality filtering and trimming of the unmerged reads with Nesoni version 0.112 . Both merged and processed unmerged reads were combined for assembly using SPAdes version 2.5.0 (Bankevich et al., 2012), followed by manual improvement of the assembly, as described previously (Sekiguchi et al., 2015). The final draft genome assembly of the Ms1 genome consists of 113 contigs. The largest and
N50 contig sizes are 251,952 and $65,925 \mathrm{bp}$, respectively. The total assembly size is 3,083,004 bp. Annotation was performed with MicroScope microbial genome annotation and analysis platform (Vallenet et al., 2013). Coding sequences (CDS) were automatically predicted, annotated and categorized by clusters of orthologous groups (COGs) using MicroScope platform. The contigs of genome sequences of $N$. mobilis Ms1 have been deposited into European Nucleotide Archive (ENA) database under the accession number FMWO01000001-FMWO01000112 (BioProject number PRJEB15545).

\section{Average Nucleotide Identity Analysis}

The average nucleotide identity (ANI) analysis was conducted to determine whether $N$. mobilis Ms1 represents distant AOB species (Konstantinidis and Tiedje, 2005). The genome sequence 


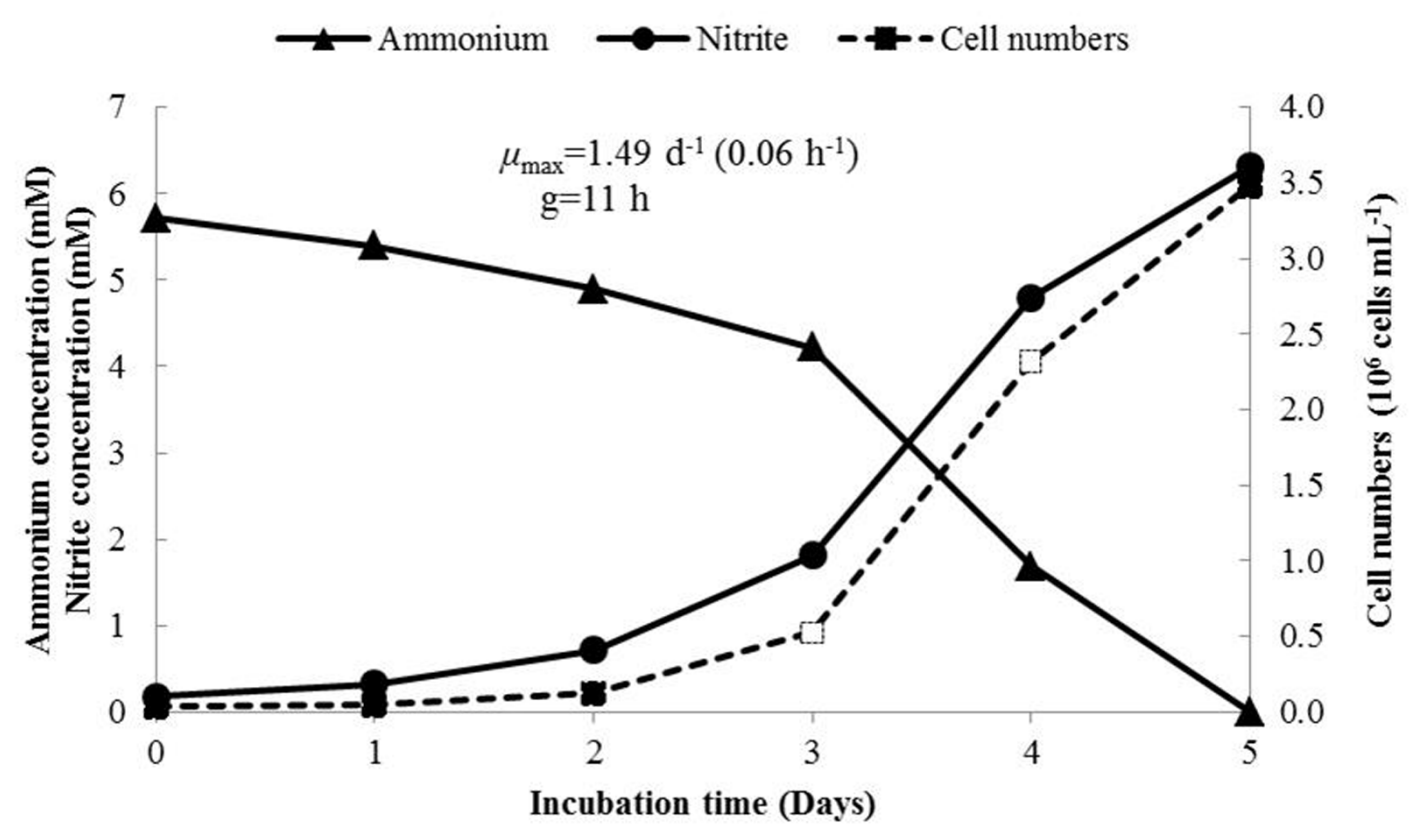

FIGURE 2 | Growth of $\boldsymbol{N}$. mobilis Ms1 determined by measurement of time courses of ammonium concentrations (triangle), nitrite concentrations (circle) and cell numbers (rectangle) during incubation for $\mathbf{5}$ days. The maximum growth rate calculated from the increased number of cells was observed on days 3 and 4 (open rectangle).

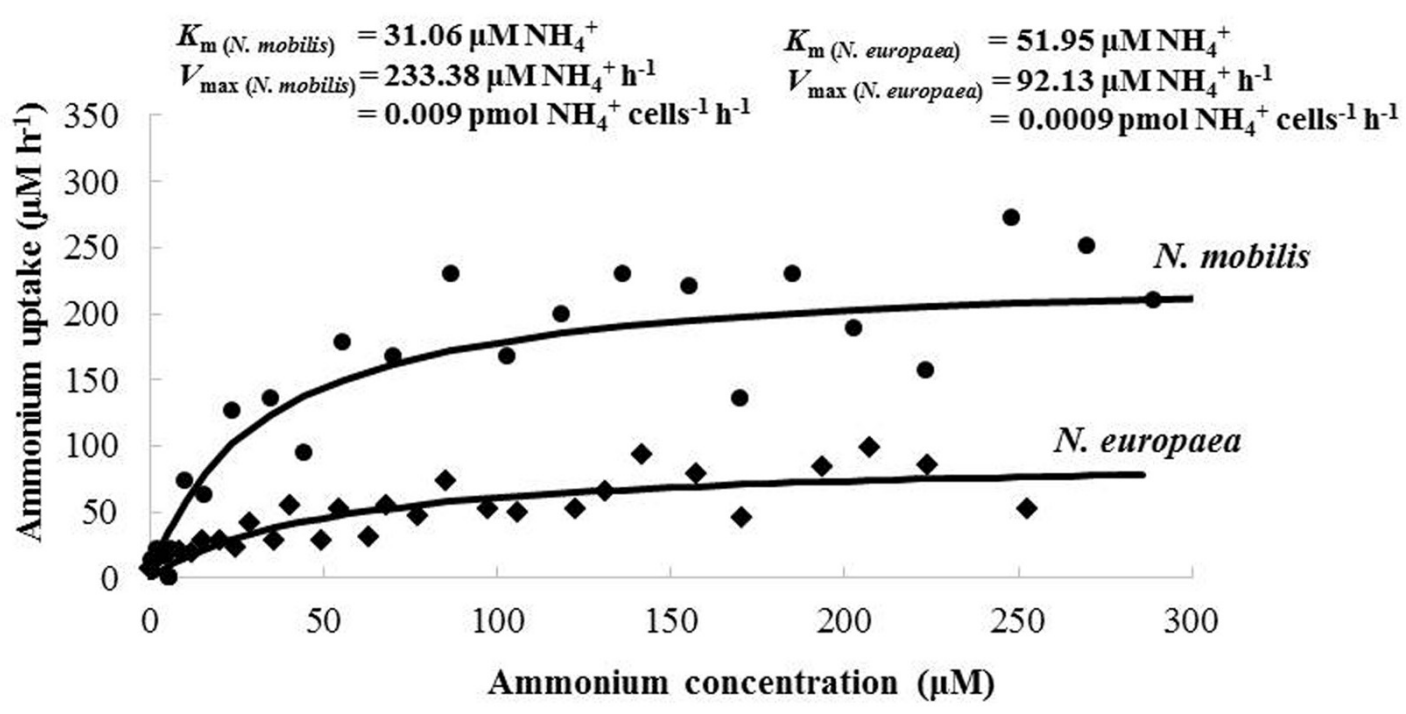

FIGURE 3 | Representative data describing ammonium uptake activities of $\boldsymbol{N}$. $\mathbf{m o b i l i s}$ Ms1 and $\boldsymbol{N}$. europaea. The best-fit curve was described according to the Michaelis-Menten equation to obtain $K_{\mathrm{m}\left(\mathrm{NH}_{4}^{+}\right)}$and $V_{\max }\left(\mathrm{NH}_{4}^{+}\right)$values.

of Nitrosomonas mobilis Ms1 was compared with the genome sequences of $N$. europaea ATCC 19718, N. eutropha C 71, Nitrosomonas sp. AL212, and Nitrosomonas sp. Is79A3. The ANI values between Ms1 and other genomes were calculated using EzGenome provided online by Jongsik Chun, Chunlab, Inc ${ }^{1}$.

${ }^{1}$ http://www.ezbiocloud.net/ezgenome/ani

\section{RESULTS AND DISCUSSION}

\section{Physiological Characteristics of}

N. mobilis Ms1

Effect of Temperature, $\mathrm{pH}$ and $\mathrm{NaCl}$ Concentration

Batch experiments were conducted to investigate the effect of temperature (Figure 1A), $\mathrm{pH}$ (Figure 1B) and $\mathrm{NaCl}$ 


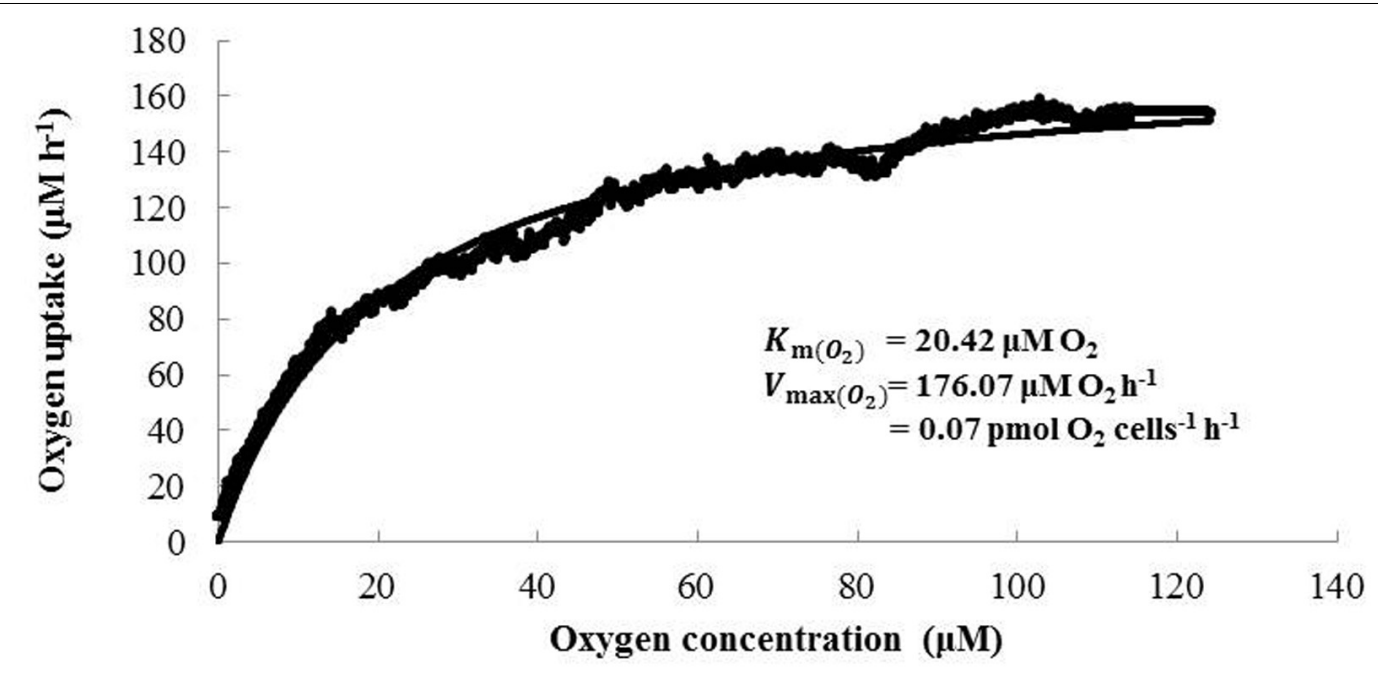

FIGURE 4 | Representative data describing oxygen uptake of $\boldsymbol{N}$. mobilis $\mathbf{M s} 1$. The best-fit curve was described according to the Michaelis-Menten equation to obtain $K_{m}\left(\mathrm{O}_{2}\right)$ and $V_{\max }\left(\mathrm{O}_{2}\right)$ values.

concentration (Figure 1C) on the growth of N. mobilis Ms1. The growth and ammonia oxidation activity were confirmed by the nitrite concentrations of the culture samples. N. mobilis Ms1 has a temperature range of $17-37^{\circ} \mathrm{C}$, with an optimum temperature of $27^{\circ} \mathrm{C}$, which is similar to the optimal ranges of other pure culture AOB strains such as Nitrosomonas europaea ATCC $25978^{\mathrm{T}}\left(25-29^{\circ} \mathrm{C}\right)$, Nitrosomonas eutropha C-91 ${ }^{\mathrm{T}}\left(30^{\circ} \mathrm{C}\right)$, Nitrosococcus mobilis $\mathrm{Nc} 2^{\mathrm{T}}\left(25-30^{\circ} \mathrm{C}\right)$ in the Nitrosomonas europaea/Nitrosomonas mobilis lineage, as well as Nitrosomonas sp. strain AL212 $\left(25^{\circ} \mathrm{C}\right)$ in the Nitrosomonas oligotropha lineage, Nitrosomonas sp. JPCCT2 $\left(28^{\circ} \mathrm{C}\right)$ in the Nitrosomonas communis lineage and Nitrosomonas stercoris KYUHI-S ${ }^{\mathrm{T}}\left(25^{\circ} \mathrm{C}\right)$ in an unclassified cluster (Table 1) (Koops et al., 1976, 1991; Suwa et al., 1997; Tokuyama et al., 1997; Itoh et al., 2013; Nakagawa and Takahashi, 2015). N. mobilis Ms1 oxidized well at pH 8.0, while other Nitrosomonas species showed their optimal oxidation at $\mathrm{pH}$ values ranging from 7.2 to 8.2 (Table 1). Similarly to N. europaea and $N$. eutropha, N. mobilis Ms1 required no salt and showed $\mathrm{NaCl}$ tolerance up to $500 \mathrm{mM}$ (Table 1). Growth temperature and $\mathrm{pH}$ ranges, and salt requirement of each strain reflect the diversity and habitat of Nitrosomonas species in both man-made and natural ecosystems (Jones et al., 1988; Koops et al., 1991, 2006; Koops and Pommerening-Roser, 2001; Cortes-Lorenzo et al., 2015).

\section{Growth Rate and Activity Kinetics}

The growth rate of $N$. mobilis Ms1 was studied in batch cultures to calculate the maximum specific growth rate $\left(\mu_{\max }\right)$ and generation time $(g)$. The initial cell concentrations were $4.07 \times 10^{4} \pm 9.87 \times 10^{3}$ cells $\mathrm{mL}^{-1}$, and the highest number of cells reached $3.53 \times 10^{6} \pm 4.12 \times 10^{5}$ cells $\mathrm{mL}^{-1}$ on day 5 of incubation. At this time, almost all ammonium in the cultures was consumed, the produced nitrite concentrations increased and ammonium concentrations decreased (Figure 2). Under the optimum conditions, the maximum specific growth rate $\left(\mu_{\max }\right)$ of $N$. mobilis Ms1 cells reached $0.06 \pm 0.01 \mathrm{~h}^{-1}$ and the generation time $(g)$ was $11.87 \pm 2.33 \mathrm{~h}$, which is in the range of previous reports for Nitrosomonas species within the N. europaea/N. mobilis lineage, as Nitrosomonas europaea and Nitrosococcus mobilis had generation times of 10-14 and 12-13 h, respectively (Table 1) (Koops et al., 1976; Belser and Schmidt, 1980). Generally, members in the N. europaea/N. mobilis lineage have a shorter generation time than other ammonia oxidizers. For example, members belonging to the $N$. oligotropha lineage and Nitrosospira lineage had generation times of 28-49 and 18-115 h, respectively, while the newly isolated highly ammonia-tolerant AOB strain, N. stercoris KYUHI-S ${ }^{\mathrm{T}}$, belonging to an unclassified cluster, had a generation time of $24 \mathrm{~h}$ (Suwa et al., 1994; Bollmann and Laanbroek, 2001; Nakagawa and Takahashi, 2015).

The activity kinetics of $N$. mobilis Ms1 were investigated using the ammonium and oxygen uptake rates. To obtain a comparable data set for ammonia oxidation activity of $N$. mobilis Ms1, the same experiment was also conducted for $N$. europaea. The $K_{\mathrm{m}\left(\mathrm{NH}_{4}^{+}\right)}$and $V_{\max \left(\mathrm{NH}_{4}^{+}\right)}$values determined from the ammonium uptake rates of $N$. mobilis $\mathrm{Ms} 1$ and $N$. europaea were $30.70 \pm 0.51 \mu \mathrm{M} \mathrm{NH}_{4}{ }^{+}$and $0.01 \pm 0.002 \mathrm{pmol}$ $\mathrm{NH}_{4}{ }^{+}$cells $^{-1} \mathrm{~h}^{-1}$, and $55.43 \pm 4.92 \mu \mathrm{M} \mathrm{NH}{ }_{4}^{+}$and $0.0009 \pm 0.00003 \mathrm{pmol} \mathrm{NH}_{4}{ }^{+}$cells $^{-1} \mathrm{~h}^{-1}(n=2)$, respectively (Figure 3). According to the calculated specific affinity from the kinetics values of ammonium uptake activities, N. mobilis Ms1 has higher substrate affinity $\left(0.33 \pm 0.06 \mathrm{~nL} \mathrm{NH}_{4}{ }^{+}\right.$ cell $\left.^{-1} \mathrm{~h}^{-1}\right)$ compared with $N$. europaea $(0.016 \pm 0.0008 \mathrm{~nL}$ $\mathrm{NH}_{4}{ }^{+}$cell $\left.{ }^{-1} \mathrm{~h}^{-1}\right)$. This result is consistent with a previous study on microbial community structure in nitrifying granules, where the population of $N$. mobilis was larger compared with $N$. europaea when the ammonia concentration in the reactor reached almost zero (Matsumoto et al., 2010).

Based on our knowledge of $N$. mobilis Ms1, this strain has a high ammonia oxidation activity, i.e., Ms1 consumes ammonium quickly during both the cultivation period of stock 
A

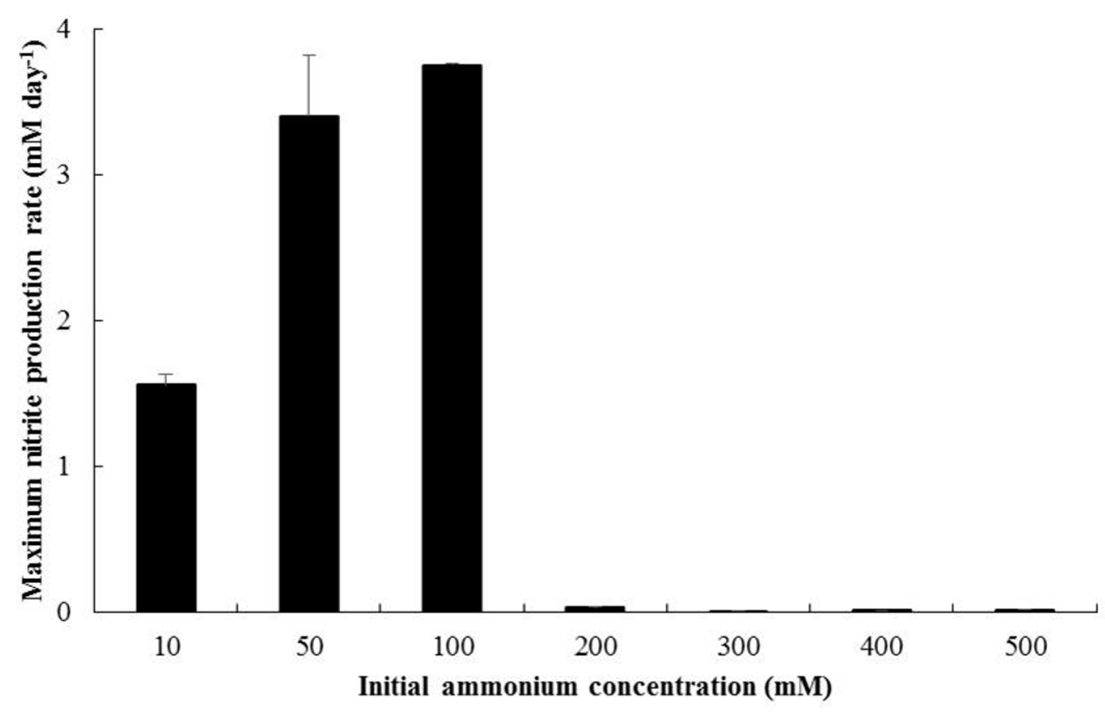

B

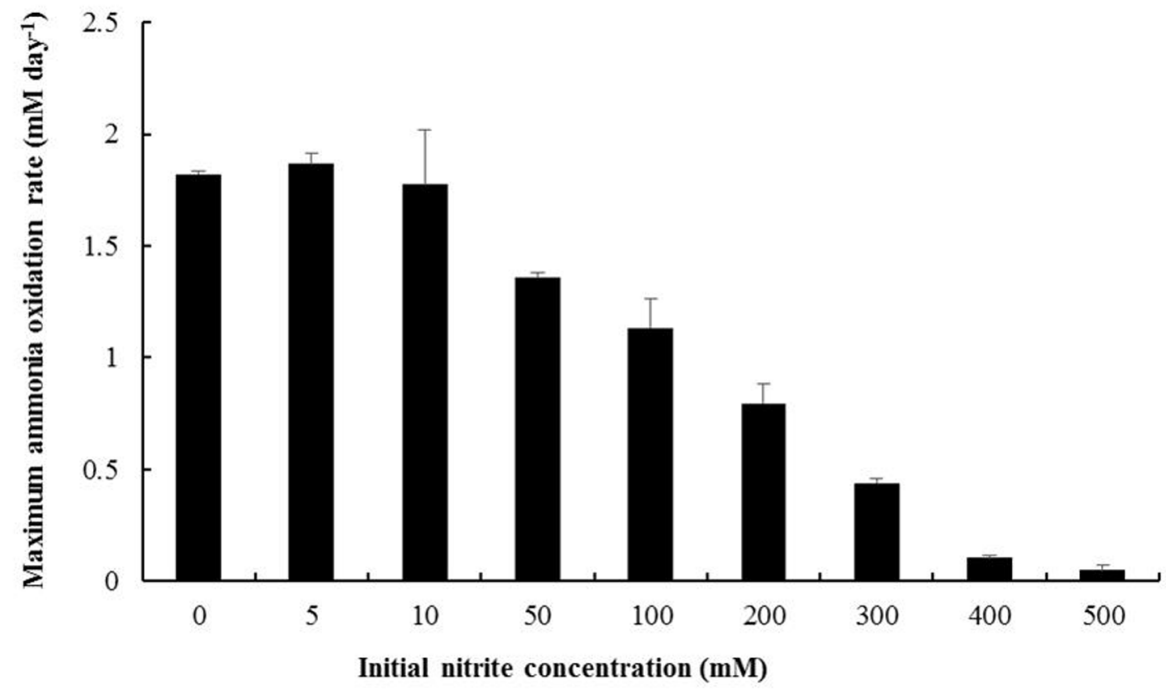

FIGURE 5 | Ammonium and nitrite tolerance of $\mathbf{N}$. mobilis Ms1. (A) Maximum produced nitrite concentration rate per day of $N$. mobilis Ms1 incubation with different initial ammonium concentrations (10,50, 100, 200, 300, 400, and $500 \mathrm{mM}$ ). (B) Maximum ammonia oxidation rate per day of $\mathrm{N}$. mobilis Ms1 incubation with different initial nitrite concentrations $(0,5,10,50,100,200,300,400$, and $500 \mathrm{mM})$ under $5 \mathrm{mM}$ initial ammonium concentration. Bars are the standard errors $(n=2)$.

cultures and the batch culture incubation for growth and activity measurements. These cultural and physiological findings were proved by the same experiment for ammonia oxidation activity of $N$. mobilis Ms1 and $N$. europaea. The $V_{\max \left(\mathrm{NH}_{4}^{+}\right)}$values of N. mobilis Ms1 (0.01 $\pm 0.002 \mathrm{pmol} \mathrm{NH}_{4}{ }^{+}$cells $\left.^{-1} \mathrm{~h}^{-1}\right)$ were higher than those of $N$. europaea $\left(0.0009 \pm 0.00003 \mathrm{pmol} \mathrm{NH}_{4}{ }^{+}\right.$ cells $\left.{ }^{-1} h^{-1}\right)$. These finding are also supported by evidence of cultivation experiments for both strains, in which the ammonium concentration of $5.0 \mathrm{mg}-\mathrm{N} \mathrm{L}^{-1}(357.14 \mu \mathrm{M})$ was completely consumed by $N$. mobilis Ms1 within an incubation time of $3 \mathrm{~h}$, but consumed by $N$. europaea in $8 \mathrm{~h}$, while their cell numbers were nearly same at $2.07 \times 10^{10}-9.55 \times 10^{10}$ cells $\mathrm{L}^{-1}$. However, the activity kinetics of the ammonia oxidizers varied, even among the same species, for example, the activity of $N$. europaea ranged from 0.001 to 0.023 pmol cells $^{-1} \mathrm{~h}^{-1}$ (Belser and Schmidt, 1980; Prosser, 1989).

The kinetics values, $K_{\mathrm{m}\left(\mathrm{O}_{2}\right)}$ and $V_{\max \left(\mathrm{O}_{2}\right)}$, for the oxygen uptake rate of $N$. mobilis Ms1 were also determined and the results showed values of $21.74 \pm 4.01 \mu \mathrm{M} \quad \mathrm{O}_{2}$ and $0.06 \pm 0.02 \quad \mathrm{pmol} \mathrm{O}_{2}$ cells $^{-1} \mathrm{~h}^{-1} \quad(n=3)$, respectively (Figure 4). This $K_{\mathrm{m}\left(\mathrm{O}_{2}\right)}$ value for $N$. mobilis $\mathrm{Ms} 1$ is comparable to those 
TABLE 2 | Genome characteristics of $\boldsymbol{N}$. mobilis Ms1 and some AOB species.

\begin{tabular}{|c|c|c|c|c|c|}
\hline Characteristics & N. mobilis Ms1 & $\begin{array}{l}\text { N. europaea } \\
\text { ATCC } 19718\end{array}$ & $\begin{array}{c}\text { N. eutropha } \\
\text { C71/C91 }\end{array}$ & $\begin{array}{c}\text { Nitrosomonas sp. } \\
\text { Is79 }\end{array}$ & $\begin{array}{l}\text { Nitrosomonas sp. } \\
\text { AL212 }\end{array}$ \\
\hline Genome size (bp) & $3,093,964$ & $2,812,094$ & $\begin{array}{c}2,661,057 \\
(2,781,824)^{a}\end{array}$ & $3,783,444$ & $\begin{array}{c}3,180,526 \\
(3,337,023)^{a}\end{array}$ \\
\hline $\begin{array}{l}\text { DNA G+C content } \\
(\%)\end{array}$ & 48.5 & 50.7 & 48.5 & 45.4 & 44.7 \\
\hline CDSs & 3075 & 2462 & 2551 & 3372 & 2983 \\
\hline $\begin{array}{l}\text { rRNA }(5 S, 16 S, \\
23 S)\end{array}$ & $1,1,1$ & $1,1,1$ & $1,1,1$ & $1,1,1$ & $1,1,1$ \\
\hline tRNA & 41 & 41 & 41 & 38 & 38 \\
\hline $\begin{array}{l}16 \mathrm{~S} \text { rRNA similarity } \\
(\mathrm{DNA})(\%)^{\dagger}\end{array}$ & $\dagger$ & 95.8 & 94.8 & 93.4 & 92.7 \\
\hline $\begin{array}{l}\text { amoA similarity } \\
(\mathrm{DNA})(\%)^{\dagger}\end{array}$ & $\dagger$ & 79.9 & 80.2 & 74.3 & 74.1 \\
\hline $\begin{array}{l}\text { amoA similarity } \\
\left(\text { amino acid) }(\%)^{\dagger}\right.\end{array}$ & $t$ & 90.9 & 89.8 & 80.3 & 80.3 \\
\hline ANI (\%)* & $*$ & 70.7 & 71.1 & 67.8 & 67.5 \\
\hline $\begin{array}{l}\text { Ammonia } \\
\text { monooxygenase } \\
(a m o C A B)\end{array}$ & $\begin{array}{c}2 \text { copies } \\
\text { NSMM_350045- } \\
\text { 350048, } \\
\text { NSMM_880001- } \\
880003\end{array}$ & $\begin{array}{c}2 \text { copies } \\
\text { NE0945-0943, } \\
\text { NE2064-2062 }\end{array}$ & $\begin{array}{l}2 \text { copies } \\
\text { Neut_2078-2076, } \\
\text { Neut_2319-2317 }\end{array}$ & $\begin{array}{c}3 \text { copies } \\
\text { Nit79A3_0471- } \\
\text { 0473, } \\
\text { Nit79A3_2886- } \\
\text { 2884, } \\
\text { Nit79A3_1079- } \\
\text { 1081 }\end{array}$ & $\begin{array}{c}3 \text { copies } \\
\text { NAL212_0797- } \\
\text { 0799, } \\
\text { NAL212_1386- } \\
\text { 1388, } \\
\text { NAL212_2606- } \\
\text { 2604 }\end{array}$ \\
\hline amoC & ND & $\begin{array}{l}1 \text { copy } \\
\text { NE1411 }\end{array}$ & $\begin{array}{c}1 \text { copy } \\
\text { Neut_1520 }\end{array}$ & $\begin{array}{c}2 \text { copies } \\
\text { Nit79A3_1233, } \\
\text { Nit79A3_1595 }\end{array}$ & $\begin{array}{c}2 \text { copies } \\
\text { NAL212_2303, } \\
\text { NAL212_2818 }\end{array}$ \\
\hline ORF4 (amoE) & $\begin{array}{c}2 \text { copies } \\
\text { NSMM_880004, } \\
\text { NSMM_350049 }\end{array}$ & $\begin{array}{l}2 \text { copies } \\
\text { NE0942, } \\
\text { NE2061 }\end{array}$ & $\begin{array}{c}2 \text { copies } \\
\text { Neut_2075, } \\
\text { Neut_2316 }\end{array}$ & $\begin{array}{c}2 \text { copies } \\
\text { Nit79A3_0474, } \\
\text { Nit79A3_2883 }\end{array}$ & $\begin{array}{c}3 \text { copies } \\
\text { NAL212_0800, } \\
\text { NAL212_2603, } \\
\text { NAL212_2819 }\end{array}$ \\
\hline ORF5 (amoD) & $\begin{array}{c}1 \text { copy } \\
\text { NSMM_880005 }\end{array}$ & $\begin{array}{l}2 \text { copies } \\
\text { NE0941, } \\
\text { NE2060 }\end{array}$ & $\begin{array}{l}2 \text { copies } \\
\text { Neut_2074, } \\
\text { Neut_2315 }\end{array}$ & $\begin{array}{c}2 \text { copies } \\
\text { Nit79A3_0475, } \\
\text { Nit79A3_2882 }\end{array}$ & $\begin{array}{l}2 \text { copies } \\
\text { NAL212_0801, } \\
\text { NAL212_2602 }\end{array}$ \\
\hline $\begin{array}{l}\text { Hydroxylamine } \\
\text { oxidoreductase } \\
\text { (haoAB) }\end{array}$ & $\begin{array}{c}2 \text { copies } \\
\text { NSMM_350001- } \\
\text { 350002, } \\
\text { NSMM_410105- } \\
\text { 410106 } \\
2 \text { haoA fragments } \\
\text { NSMM_360037, } \\
\text { NSMM_640011 }\end{array}$ & $\begin{array}{c}3 \text { copies } \\
\text { NE0962-0961, } \\
\text { NE2044-2043, } \\
\text { NE2339-2338 }\end{array}$ & $\begin{array}{c}\text { 3 copies } \\
\text { Neut_1672-1671, } \\
\text { Neut_1793-1792, } \\
\text { Neut_2335-2334 }\end{array}$ & $\begin{array}{c}3 \text { copies } \\
\text { Nit79A3_0807- } \\
\text { 0808, } \\
\text { Nit79A3_0822- } \\
\text { 0823, } \\
\text { Nit79A3_2942- } \\
\text { 2941 }\end{array}$ & $\begin{array}{c}3 \text { copies } \\
\text { NAL212_1807- } \\
\text { 1806, } \\
\text { NAL212_2138- } \\
\text { 2137, } \\
\text { NAL212_2750- } \\
2749\end{array}$ \\
\hline $\begin{array}{l}\text { Cytochrome c-554 } \\
(\text { cycA) }\end{array}$ & $\begin{array}{c}2 \text { copies } \\
\text { NSMM_350003, } \\
\text { NSMM_410107 } \\
2 \text { cycA fragments } \\
\text { NSMM_560024, } \\
\text { NSMM_860012 }\end{array}$ & $\begin{array}{l}3 \text { copies } \\
\text { NE0960, } \\
\text { NE2042, } \\
\text { NE2337 }\end{array}$ & $\begin{array}{l}3 \text { copies } \\
\text { Neut_1670, } \\
\text { Neut_1791, } \\
\text { Neut_2333 }\end{array}$ & $\begin{array}{c}3 \text { copies } \\
\text { Nit79A3_0809, } \\
\text { Nit79A3_0824, } \\
\text { Nit79A3_2940 }\end{array}$ & $\begin{array}{l}3 \text { copies } \\
\text { NAL212_1805, } \\
\text { NAL212_2136, } \\
\text { NAL212_2748 }\end{array}$ \\
\hline Cytochrome & 2 copies & 2 copies & 2 copies & 3 copies & 3 copies \\
\hline $\begin{array}{l}\mathrm{c}_{\mathrm{M}}-552 \\
(\text { cycB/cycX) }\end{array}$ & $\begin{array}{l}\text { NSMM_560023, } \\
\text { NSMM_860011 }\end{array}$ & $\begin{array}{l}\text { NE0959, } \\
\text { NE2336 }\end{array}$ & $\begin{array}{l}\text { Neut_1790, } \\
\text { Neut_2332 }\end{array}$ & $\begin{array}{l}\text { Nit79A3_0810, } \\
\text { Nit79A3_0825, } \\
\text { Nit79A3_2939 }\end{array}$ & $\begin{array}{l}\text { NAL212_1804, } \\
\text { NAL212_2747, } \\
\text { NAL212_2135 }\end{array}$ \\
\hline Nitrosocyanin & $\begin{array}{c}1 \text { copy } \\
\text { NSMM_680003 }\end{array}$ & $\begin{array}{c}1 \text { copy } \\
\text { NE0143 }\end{array}$ & $\begin{array}{c}1 \text { copy } \\
\text { Neut_2173 }\end{array}$ & - & $\begin{array}{c}1 \text { copy } \\
\text { NAL212_0897 }\end{array}$ \\
\hline $\begin{array}{l}\text { Copper-containing } \\
\text { nitrite reductase, } \\
\text { nirk }\end{array}$ & $\begin{array}{c}1 \text { copy } \\
\text { NSMM_600004 }\end{array}$ & $\begin{array}{l}1 \text { copy } \\
\text { NE0924 }\end{array}$ & $\begin{array}{c}1 \text { copy } \\
\text { Neut_1403 }\end{array}$ & $\begin{array}{c}1 \text { copy } \\
\text { Nit79A3_2335 }\end{array}$ & $\begin{array}{c}1 \text { copy } \\
\text { NAL212_2392 }\end{array}$ \\
\hline $\begin{array}{l}\text { Nitric oxide } \\
\text { reductase cNOR } \\
\text { (norCBQD) }\end{array}$ & $\begin{array}{c}1 \text { copy } \\
\text { NSMM_630006- } \\
630008, \\
\text { NSMM_400223 }\end{array}$ & $\begin{array}{c}1 \text { copy } \\
\text { NE2003-2006 }\end{array}$ & $\begin{array}{c}1 \text { copy } \\
\text { Neut_0518-0521 }\end{array}$ & - & $\begin{array}{c}1 \text { copy } \\
\text { NAL212_0538- } \\
0541\end{array}$ \\
\hline
\end{tabular}

(Continued) 
TABLE 2 | Continued

\begin{tabular}{|c|c|c|c|c|c|}
\hline Characteristics & N. mobilis Ms1 & $\begin{array}{l}\text { N. europaea } \\
\text { ATCC } 19718\end{array}$ & $\begin{array}{c}\text { N. eutropha } \\
\text { C71/C91 }\end{array}$ & $\begin{array}{c}\text { Nitrosomonas sp. } \\
\text { Is79 }\end{array}$ & $\begin{array}{c}\text { Nitrosomonas sp. } \\
\text { AL212 }\end{array}$ \\
\hline $\begin{array}{l}\text { Haem-copper nitric } \\
\text { oxide reductase } \\
\text { sNOR } \\
\text { (norSY-SenC) }\end{array}$ & $\begin{array}{c}1 \text { copy } \\
\text { NSMM_310017- } \\
310019\end{array}$ & $\begin{array}{c}1 \text { copy } \\
\text { NE0682-0684 }\end{array}$ & $\begin{array}{c}1 \text { copy } \\
\text { Neut_1874-1876 }\end{array}$ & - & - \\
\hline $\begin{array}{l}\text { Cytochrome c' } \\
\text { beta (cytS) }\end{array}$ & $\begin{array}{c}1 \text { copy } \\
\text { NSMM_340048 }\end{array}$ & $\begin{array}{l}1 \text { copy } \\
\text { NE0824 }\end{array}$ & $\begin{array}{c}1 \text { copy } \\
\text { Neut_1345 }\end{array}$ & $\begin{array}{c}1 \text { copy } \\
\text { Nit79A3_0363 }\end{array}$ & $\begin{array}{c}1 \text { copy } \\
\text { NAL212_3151 }\end{array}$ \\
\hline $\begin{array}{l}\text { Cytochrome P460 } \\
\text { (cytL) }\end{array}$ & $\begin{array}{c}2 \text { copies } \\
\text { NSMM_320010 } \\
\text { NSMM_810003 }\end{array}$ & $\begin{array}{l}1 \text { copy } \\
\text { NE0011 }\end{array}$ & $\begin{array}{c}1 \text { copy } \\
\text { Neut_0132 }\end{array}$ & $\begin{array}{c}1 \text { copy } \\
\text { Nit79A3_1628 }\end{array}$ & $\begin{array}{c}2 \text { copies } \\
\text { NAL212_0896, } \\
\text { NAL212_0043 }\end{array}$ \\
\hline Origin & Nitrifying granules & Wastewater & Municipal sewage & Fresh water & Activated sludge \\
\hline $\begin{array}{l}\text { Bioproject } \\
\text { accession number }\end{array}$ & PRJEB15545 & PRJNA52 & PRJNA13913 & PRJNA52837 & PRJNA32989 \\
\hline Reference & This study & Chain et al., 2003 & Stein et al., 2007 & $\begin{array}{l}\text { Bollmann et al., } \\
2013\end{array}$ & Suwa et al., 2011 \\
\hline
\end{tabular}

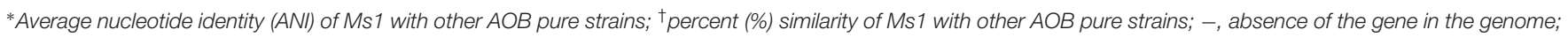

a size including plasmids; $N D$, not detected in the genome.

reported in a previous study for oxygen consumption kinetics of $N$. europaea ATCC $19178^{\mathrm{T}}$ at a high growth rate and high oxygen concentration $\left[K_{\mathrm{m}}\left(\mathrm{O}_{2}\right)=3.0-14.9 \mu \mathrm{M} \mathrm{O}_{2}\right]$ (Laanbroek and Gerards, 1993). The respiratory cytochrome c oxidases of the nitrifiers are responsible for maintaining their electron chain and adapting to the environment at different oxygen levels (Klotz and Stein, 2011). N. europaea and N. mobilis Ms1 possess the cytochrome aa3 type oxidase, which functions as the low affinity $\mathrm{O}_{2}$ reductase whereas $N$. eutropha possesses cytochrome cbb3 type oxidase, which functions as the high affinity $\mathrm{O}_{2}$ reductase, in addition to cytochrome aa3 and bo3 type oxidases (Stein et al., 2007; Klotz and Stein, 2011). It is likely that N. mobilis Ms1 might not adapt to an environment at different oxygen levels.

\section{Ammonium and Nitrite Tolerance}

$N$. mobilis Ms1 exhibits ammonia oxidizing ability at the concentrations of ammonium up to $100 \mathrm{mM}\left(1,400 \mathrm{mg}-\mathrm{N} \mathrm{L}^{-1}\right)$ (Figure 5A). In tests of nitrite tolerance, although inhibition of ammonia oxidation was observed in cultures with concentrations of nitrite of $50 \mathrm{mM}$ and higher (Figure 5B), the initially provided ammonium $(5 \mathrm{mM})$ was finally consumed in cultures with nitrite concentrations of up to $300 \mathrm{mM}$. Taken together, N. mobilis Ms1 had high ammonium and nitrite tolerance, although the strain was enriched from the nitrifying granules of a low ammonium influent bioreactor and could grow in culture media with only $30 \mathrm{mg}-\mathrm{N} \mathrm{L}^{-1}(2.14 \mathrm{mM})$ of ammonium substrate. These characteristics are consistent with those reported in a previous study by Juretschko et al. (1998), where N. mobilis-like bacteria were dominant in sludge with high ammonium concentrations of up to $5,000 \mathrm{mg}-\mathrm{N} \mathrm{L}^{-1}$ (357.14 mM) in a wastewater treatment plant. Among members of the genus Nitrosomonas, Nitrosomonas nitrosa isolated from a eutrophic environment exhibited the same ammonium tolerance as $N$. mobilis Ms1, of up to $100 \mathrm{mM}$ (Koops et al., 1991). In contrast, Nitrosomonas sp. strain AL212 belonging to the $N$. oligotropha lineage isolated from activated sludge exhibited the maximum ammonium tolerance of $10.7 \mathrm{mM}$ (Suwa et al., 1997), which is about 10 times lower than that of N. mobilis Ms1 (100 mM). The results of the pure culture study also support the previous findings for $\mathrm{AOB}$ communities in which the N. oligotropha cluster was predominant over the $N$. europaea-N. mobilis cluster in activated sludge with low ammonium concentrations (Limpiyakorn et al., 2005, 2007). Within Nitrosomonas cluster 7, Nitrosococcus mobilis Nc2, which is phylogenetically similar to N. mobilis Ms1, was tolerant to ammonium concentration at up to $300 \mathrm{mM}$ (Koops et al., 1990), while $N$. europaea and $N$. eutropha-like species were tolerant of up to 400 and $600 \mathrm{mM}$ of ammonium, respectively (Koops et al., 1991). Nitrosomonas stercoris KYUHI-S ${ }^{\mathrm{T}}$ isolated from compost (Nakagawa and Takahashi, 2015) exhibited the highest ammonium tolerance $(1,000 \mathrm{mM})$ among Nitrosomonas strains (Table 1). Although the nitrite tolerance of ammonia oxidizers was not surprising because of the accumulation of nitrite during cultivation and enrichment, the $300 \mathrm{mM}$ of nitrite tolerance of $N$. mobilis Ms1 was extremely high among strains isolated from the activated sludge and wastewater treatment plants. For example, the ammonia monooxygenase (AMO) activity of N. europaea was inhibited by $20 \mathrm{mM}$ of nitrite (Stein and Arp, 1998; Cua and Stein, 2011). However, the high nitrite tolerance of $N$. mobilis Ms1 is consistent with the results of previous studies that showed enriched cultures of ammonia oxidizers had nitrite tolerance of up to $500 \mathrm{mM}$, most clones fell into the Nitrosomonas europaea/Nitrosomonas mobilis cluster (Tan et al., 2008), and nitrite effects on ammonia oxidizing activity varied between Nitrosomonas europaea and closely related Nitrosomonas eutropha (Cua and Stein, 2011).

\section{Genome Overview of $\boldsymbol{N}$. mobilis Ms1}

The genome of N. mobilis Ms1 has a sequence length of 3.09 $\mathrm{Mbp}$ and a $\mathrm{G}+\mathrm{C}$ content of $48.53 \%$. The genome included 3075 protein-coding DNA sequences (CDSs), 41 tRNA genes, and a single copy of the 16S-23S-5S rRNA operon. Based on phylogenetic analyses of $N$. mobilis Ms1 with other AOB (Fujitani et al., 2015), Ms1 showed the greatest similarity to Nitrosomonas sp. strains Nm107 and Nm104 (99.7-100\%) at 


\section{A}

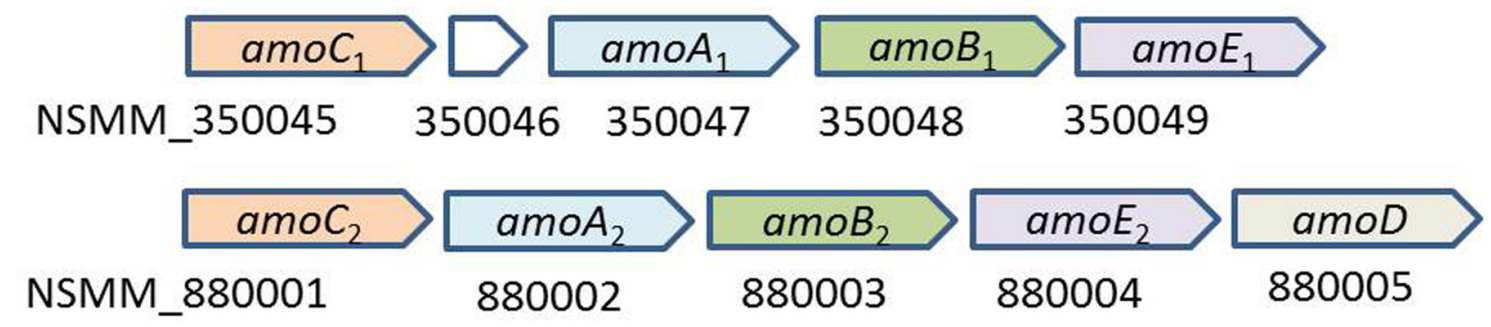

B

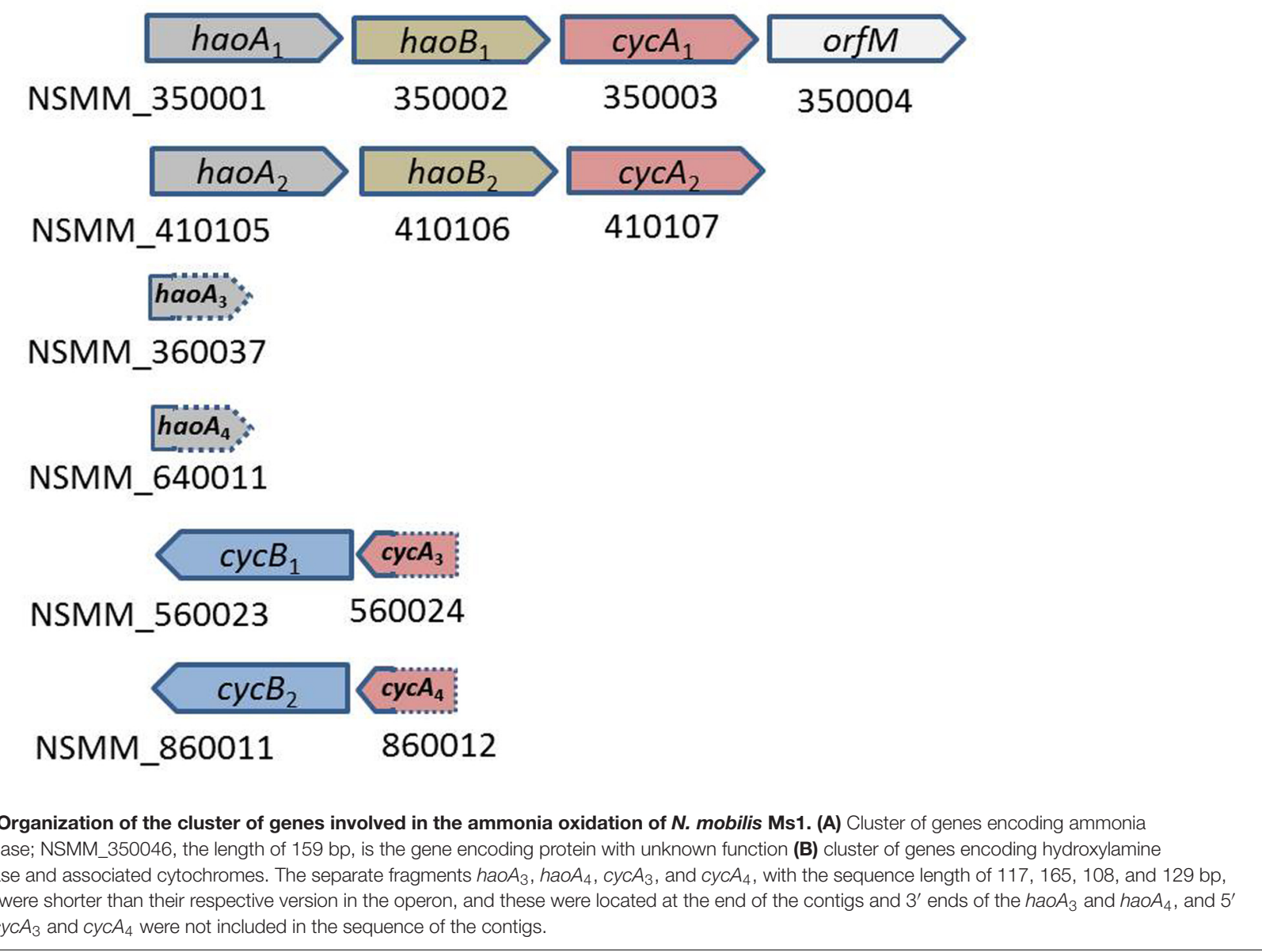

the 16S rRNA and amoA genes levels and 99.6\% similarity to Nitrosococcus mobilis $\mathrm{Nc} 2$ at the 16S rRNA gene level, therefore Ms1 was attributed to the N. mobilis lineage. Similarities between $N$. mobilis Ms1 and other currently available genomes of Nitrosomonas species at 16S rRNA gene level and amoA amino acid level were highest to Nitrosomonas europaea ATCC 19718, 95.8 and 90.9\%, respectively, and the similarity at the genomes level (ANI values) was highest to N. eutropha C-91, $71.1 \%$ (Table 2), confirming N. mobilis Ms1 was significantly below the species cut-off point for delineation (Konstantinidis et al., 2006). The smaller similarities of whole genomes and $16 \mathrm{~S}$ rRNA and amoA sequences between N. mobilis Ms1 and other Nitrosomonas species support the physiological uniqueness of N. mobilis Ms1 among other Nitrosomonas species. The general genome features and the inventory of genes involved in the ammonia oxidation and nitrogen oxide metabolism of N. mobilis Ms1 and some currently available genomes of AOB are categorized in Table 2.

N. mobilis Ms1 uses ammonia as an energy source in the same manner as other AOB. The genome of $N$. mobilis Ms1 contains two copies of the gene cluster encoding ammonia monooxygenase $(a m o C A B)$, followed by two copies of the $a m o E D$ operon in which $a m o D$ in the first operon was not identified (Figure 6A; Table 2). N. mobilis Ms1 contains the 
operons encoding hydroxylamine oxidoreductase with associated cytochromes $\mathrm{c} 554$ and $\mathrm{c}_{\mathrm{M}} 552$ (hao $A B-c y c A B$ ) in two copies, neither of which includes $c y c B$, whereas other $A O B$ genomes contain two to three copies of the complete hao $A B-c y c A B$ operons (Figure 6B; Table 2) (Chain et al., 2003; Stein et al., 2007; Suwa et al., 2011). Unlike other AOB, the two small hao $A$ fragments, which are distantly located from the hao $A B$ $c y c A$ operons and two copies of $c y c B$-fragment $c y c A$ operon, but not adjacent to hao, were also identified in the $N$. mobilis Msl genome. The additional amoC singleton gene, which has been found in most other AOB genomes, was not identified in N. mobilis Ms1. As in other AOB, except Nitrosomonas sp. Is79 (Bollmann et al., 2013), the N. mobilis Ms1 genome contains an AOB-specific red-copper protein, nitrosocyanin, which has been proposed to be involved in electron transport, although the detailed vital function of this protein has not been identified (Klotz and Stein, 2011; Stein et al., 2013).

Ammonia-oxidizing bacteria are known to produce nitric oxide (NO) and nitrous oxide $\left(\mathrm{N}_{2} \mathrm{O}\right)$, a greenhouse gas, from the hydroxylamine oxidation (a part of ammonia oxidation), nitrifier denitrification (dissimilatory nitrite reduction) and NO detoxification (nitrosative stress) pathways (Klotz and Stein, 2011). The genes encoding copper-containing nitrite reductase (NirK), membrane-bound cytochrome c nitric oxide reductase cNOR (norCBQD), heme-copper nitric oxide reductase sNOR (norSY-SenC), cytochrome $c^{\prime}$ beta $(c y t S)$ and cytochrome P460 $(c y t L)$, all of which are supposed to be involved in the oxidation of hydroxylamine, the nitrifier partial denitrifying process and NO-detoxification, were identified in the N. mobilis Ms1 genome, whereas one or both types of nitric oxide reductase were not identified in the Nitrosomonas sp. AL212 and Nitrosomonas sp. Is79 genomes (Table 2) (Klotz and Stein, 2011; Suwa et al., 2011; Bollmann et al., 2013). Unlike other AOB, the gene encoding nitric oxide reductase activation protein (norD) did not cluster with norCBQ in the N. mobilis Ms1 genome (Table 2). Overall, the gene contents and the organization of the genes involved in N. mobilis Ms1 were distinct compared to other AOB genomes.

\section{CONCLUSION}

The key physiological and genomic properties of $N$. mobilis Ms1 were investigated in this study. The temperature and $\mathrm{pH}$ ranges and the growth rate of $N$. mobilis Ms1 were within the ranges of other Nitrosomonas species in the Nitrosomonas

\section{REFERENCES}

Bankevich, A., Nurk, S., Antipov, D., Gurevich, A. A., Dvorkin, M., Kulikov, A. S., et al. (2012). SPAdes: a new genome assembly algorithm and its applications to single-cell sequencing. J. Comput. Biol. 19, 455-477. doi: 10.1089/cmb.2012. 0021

Belser, L. W., and Schmidt, E. L. (1980). Growth and oxidation kinetics of 3 genera of ammonia oxidizing nitrifiers. FEMS Microbiol. Lett. 7, 213-216. doi: 10.1016/S0378-1097(80)80033-4
europaea/Nitrosomonas mobilis lineage, supporting the previous findings regarding the codominant habitat of $N$. mobilislike bacteria with $N$. europaea-N. eutropha-like bacteria in wastewater treatment systems. In addition, N. mobilis Ms1 can withstand the high ammonia and nitrite concentrations. These physiological findings reveal the habitat and ecophysiology of $N$. mobilis in the natural ecosystem. Because N. mobilis Ms1 can oxidize at high ammonium and nitrite concentrations, $N$. mobilis-like strains would be dominant in environments such as wastewater treatment plants where the ammonia and nitrite concentrations are rather high. The genomic information for N. mobilis Ms1 is the first genome sequence of Nitrosomonas mobilis-like bacteria. The genome analysis of N. mobilis Ms1 also indicated that this strain has distinct genome features compared with the other Nitrosomonas species, although other functional genes and unique gene characteristics of Ms1 still needed to be investigated. Overall, the results of the present study provide a better understanding of the ecophysiology of Nitrosomonas mobilis and other nitrifying bacteria, especially among the widely abundant Nitrosomonas species in both natural and wastewater treatment systems.

\section{AUTHOR CONTRIBUTIONS}

SMT, NU, HF, and ST designed the experiments. SMT performed all experiments. SMT, NU, HF, and ST analyzed the data. YS performed and wrote genome sequencing and assembly. SMT performed genome analysis. NU performed ANI analysis. SMT drafted the manuscript. SMT, NU, HF, YS, and ST read and edited the manuscript.

\section{FUNDING}

This research was funded by the Special Research Projects (2014B-323, 2015K-218) program of Waseda University and the Large Research Projects program of the Institute for Fermentation, Osaka.

\section{ACKNOWLEDGMENTS}

The authors thank Dr. Akihiko Terada, Tokyo University of Agricultural Technology, for providing equipment and the facility for measurement of oxygen uptake.

Bollmann, A., and Laanbroek, H. J. (2001). Continuous culture enrichments of ammonia-oxidizing bacteria at low ammonium concentrations. FEMS Microbiol. Ecol. 37, 211-221. doi: 10.1016/s0168-6496(01)00163-5

Bollmann, A., Sedlacek, C. J., Norton, J., Laanbroek, H. J., Suwa, Y., Stein, L. Y., et al. (2013). Complete genome sequence of Nitrosomonas sp. Is79, an ammonia oxidizing bacterium adapted to low ammonium concentrations. Stand. Genomic Sci. 7, 469-482. doi: 10.4056/sigs.3517166

Campbell, M. A., Chain, P. S. G., Dang, H., El Sheikh, A. F., Norton, J. M., Ward, N. L., et al. (2011). Nitrosococcus watsonii sp. nov., 
a new species of marine obligate ammonia-oxidizing bacteria that is not omnipresent in the world's oceans: calls to validate the names 'Nitrosococcus halophilus' and 'Nitrosomonas mobilis'. FEMS Microbiol. Ecol. 76, 39-48. doi: 10.1111/j.1574-6941.2010.01027.x

Cantera, J. J. L., and Stein, L. Y. (2007). Molecular diversity of nitrite reductase genes (nirK) in nitrifying bacteria. Environ. Microbiol. 9, 765-776. doi: 10.1111/ j.1462-2920.2006.01198.x

Chain, P., Lamerdin, J., Larimer, F., Regala, W., Lao, V., Land, M., et al. (2003). Complete genome sequence of the ammonia-oxidizing bacterium and obligate chemolithoautotroph Nitrosomonas europaea. J. Bacteriol. 185, 2759-2773. doi: 10.1128/JB.185.21.6496.2003

Chen, G. H., and Wong, M. T. (2004). Impact of increased chloride concentration on nitrifying-activated sludge cultures. J. Environ. Eng. 130, 116-125. doi: 10. 1061/(asce)0733-9372(2004)130:2(116)

Cortes-Lorenzo, C., Rodriguez-Diaz, M., Sipkema, D., Juarez-Jimenez, B., Rodelas, B., Smidt, H., et al. (2015). Effect of salinity on nitrification efficiency and structure of ammonia-oxidizing bacterial communities in a submerged fixed bed bioreactor. Chem. Eng. J. 266, 233-240. doi: 10.1016/j.cej.2014.12.083

Cua, L. S., and Stein, L. Y. (2011). Effects of nitrite on ammonia-oxidizing activity and gene regulation in three ammonia-oxidizing bacteria. FEMS Microbiol. Lett. 319, 169-175. doi: 10.1111/j.1574-6968.2011.02277.x

Daims, H., Lebedeva, E. V., Pjevac, P., Han, P., Herbold, C., Albertsen, M., et al. (2015). Complete nitrification by Nitrospira bacteria. Nature 528, 504-509. doi: 10.1038/nature16461

Fujitani, H., Kumagai, A., Ushiki, N., Momiuchi, K., and Tsuneda, S. (2015). Selective isolation of ammonia-oxidizing bacteria from autotrophic nitrifying granules by applying cell-sorting and sub-culturing of microcolonies. Front. Microbiol. 6:1159. doi: 10.3389/fmicb.2015.01159

Gieseke, A., Bjerrum, L., Wagner, M., and Amann, R. (2003). Structure and activity of multiple nitrifying bacterial populations co-existing in a biofilm. Environ. Microbiol. 5, 355-369. doi: 10.1046/j.1462-2920.2003.00423.x

Griess-Romijn van Eck, E. (1966). Physiological and Chemical Tests for Drinking Water. NEN 1056, IV-2. Rijswijk: Nederlands Normalisatie Instituut.

Head, I. M., Hiorns, W. D., Embley, T. M., McCarthy, A. J., and Saunders, J. R. (1993). The phylogeny of autotrophic ammonia-oxidizing bacteria as determined by analysis of 16 s ribosomal RNA gene sequences. J. Gen. Microbiol. 139, 1147-1153. doi: 10.1099/00221287-139-6-1147

Itoh, Y., Sakagami, K., Uchino, Y., Boonmak, C., Oriyama, T., Tojo, F., et al. (2013). Isolation and characterization of a thermotolerant ammonia-oxidizing bacterium Nitrosomonas sp JPCCT2 from a thermal power station. Microbes Environ. 28, 432-435. doi: 10.1264/jsme2.ME13058

Jones, R. D., Morita, R. Y., Koops, H. P., and Watson, S. W. (1988). A new marine ammonium-oxidizing bacterium, Nitrosomonas cryotolerans sp nov. Can. J. Microbiol. 34, 1122-1128. doi: 10.1139/m88-198

Juretschko, S., Timmermann, G., Schmid, M., Schleifer, K. H., PommereningRoser, A., Koops, H. P., et al. (1998). Combined molecular and conventional analyses of nitrifying bacterium diversity in activated sludge: Nitrosococcus mobilis and Nitrospira-like bacteria as dominant populations. Appl. Environ. Microbiol. 64, 3042-3051.

Kandeler, E., and Gerber, H. (1988). Short-term assay of soil urease activity using colorimetric determination of ammonium. Biol. Fertil. Soils 6, 68-72. doi: 10. 1007/BF00257924

Klotz, M. G., and Stein, L. Y. (2011). "Genomics of ammonia-oxidizing bacteria and insights to their evolution," in Nitrification, eds B. B. Ward, D. J. Arp, and M. G. Klotz (Washington, DC: ASMPress), 57-94.

Konstantinidis, K. T., Ramette, A., and Tiedje, J. M. (2006). The bacterial species definition in the genomic era. Phil. Trans. Soc. B 361, 1929-1940. doi: 10.1098/ rstb.2006.1920

Konstantinidis, K. T., and Tiedje, J. M. (2005). Genomic insights that advance the species definition for prokaryotes. Proc. Natl. Acad. Sci. U.S.A. 102, 2567-2572. doi: 10.1073/pnas.0409727102

Koops, H. P., Bottcher, B., Moller, U. C., Pommereningroser, A., and Stehr, G. (1990). Description of a new species of Nitrosococcus. Arch. Microbiol. 154, 244-248. doi: 10.1007/bf00248962

Koops, H. P., Bottcher, B., Moller, U. C., Pommereningroser, A., and Stehr, G. (1991). Classification of eight new species of ammonia-oxidizing bacteria: Nitrosomonas communis sp. nov., Nitrosomonas ureae sp. nov., Nitrosomonas aestuarii sp. nov., Nitrosomonas marina sp. nov., Nitrosomonas nitrosa sp. nov., Nitrosomonas eutropha sp. nov., Nitrosomonas oligotropha sp. nov. and Nitrosomonas halophila sp. nov. J. Gen. Microbiol. 137, 1689-1699.

Koops, H. P., and Harms, H. (1985). Deoxyribonucleic acid homologies among 96 strains of ammonia-oxidizing bacteria. Arch. Microbiol. 141, 214-218. doi: 10.1007/bf00408061

Koops, H. P., Harms, H., and Wehrmann, H. (1976). Isolation of a moderate halophilic ammonia-oxidizing bacterium, Nitrosococcus mobilis nov sp. Arch. Microbiol. 107, 277-282. doi: 10.1007/bf00425339

Koops, H. P., and Pommerening-Roser, A. (2001). Distribution and ecophysiology of the nitrifying bacteria emphasizing cultured species. FEMS Microbiol. Ecol. 37, 1-9. doi: 10.1111/j.1574-6941.2001.tb00847.x

Koops, H. P., Purkhold, U., Pommerening-Roser, A., Timmermann, G., and Wagner, M. (2006). The lithoautotrophic ammonia-oxidizing bacteria," in Prokaryotes: a Handbook on the Biology of Bacteria, Proteobacteria: Alpha and Beta Subclasses, Vol 5, 3rd Edn, eds M. Dworkin, S. Falkow, E. Rosenberg, K.-H. Schleifer, and E. Stackebrandt (New York, NY: Springer), 778-811. doi: 10.1007/0-387-30745- $1 \backslash_{3} 6$

Laanbroek, H. J., and Gerards, S. (1993). Competition for limiting amounts of oxygen between Nitrosomonas europaea and Nitrobacter winogradskyi grown in mixed continuous cultures. Arch. Microbiol. 159, 453-459. doi: 10.1007/bf 00288593

Limpiyakorn, T., Kurisu, F., Sakamoto, Y., and Yagi, O. (2007). Effects of ammonium and nitrite on communities and populations of ammonia-oxidizing bacteria in laboratory-scale continuous-flow reactors. FEMS Microbiol. Ecol. 60, 501-512. doi: 10.1111/j.1574-6941.2007.00307.x

Limpiyakorn, T., Shinohara, Y., Kurisu, F., and Yagi, O. (2005). Communities of ammonia-oxidizing bacteria in activated sludge of various sewage treatment plants in Tokyo. FEMS Microbiol. Ecol. 54, 205-217. doi: 10.1016/j.femsec.2005. 03.017

Matsumoto, S., Ishikawa, D., Saeki, G., Aoi, Y., and Tsuneda, S. (2010). Microbial population dynamics and community structure during the formation of nitrifying granules to treat ammonia-rich inorganic wastewater. Microbes Environ. 25, 164-170. doi: 10.1264/jsme2.ME10107

Mota, C., Head, M. A., Ridenoure, J. A., Cheng, J. J., and de los Reyes, F. L. (2005). Effects of aeration cycles on nitrifying bacterial populations and nitrogen removal in intermittently aerated reactors. Appl. Environ. Microbiol. 71, 8565-8572. doi: 10.1128/aem.71.12.8565-8572.2005

Nakagawa, T., and Takahashi, R. (2015). Nitrosomonas stercoris sp nov., a chemoautotrophic ammonia-oxidizing bacterium tolerant of high ammonium isolated from composted cattle manure. Microbes Environ. 30, 221-227. doi: 10.1264/jsme2.ME15072

Pommerening-Roser, A., Rath, G., and Koops, H. P. (1996). Phylogenetic diversity within the genus Nitrosomonas. Syst. Appl. Microbiol. 19, 344-351. doi: 10.1016/ S0723-2020(96)80061-0

Prosser, J. I. (1989). Autotrophic nitrification in bacteria. Adv. Microb. Physiol. 30, 125-181. doi: 10.1016/S0065-2911(08)60112-5

Purkhold, U., Pommerening-Roser, A., Juretschko, S., Schmid, M. C., Koops, H. P., and Wagner, M. (2000). Phylogeny of all recognized species of ammonia oxidizers based on comparative 16S rRNA and amoA sequence analysis: implications for molecular diversity surveys. Appl. Environ. Microbiol. 66, 5368-5382. doi: 10.1128/aem.66.12.5368-5382.2000

Radniecki, T. S., and Ely, R. L. (2008). Zinc chloride inhibition of Nitrosococcus mobilis. Biotechnol. Bioeng. 99, 1085-1095. doi: 10.1002/bit.21672

Radniecki, T. S., and Ely, R. L. (2011). Transcriptional and physiological responses of Nitrosococcus mobilis to copper exposure. J. Environ. Eng. 137, 307-314. doi: 10.1061/(asce)ee.1943-7870.0000338

Sekiguchi, Y., Ohashi, A., Parks, D. H., Yamauchi, T., Tyson, G. W., and Hugenholtz, P. (2015). First genomic insights into members of a candidate bacterial phylum responsible for wastewater bulking. PeerJ 3:e740. doi: 10.7717/ peerj.740

Stehr, G., Bottcher, B., Dittberner, P., Rath, G., and Koops, H. P. (1995). The ammonia-oxidizing nitrifying population of the river elbe estury. FEMS Microbiol. Ecol. 17, 177-186. doi: 10.1111/j.1574-6941.1995.tb00141.x

Stein, L. Y., and Arp, D. J. (1998). Loss of ammonia monooxygenase activity in Nitrosomonas europaea upon exposure to nitrite. Appl. Environ. Microbiol. 64, 4098-4102.

Stein, L. Y., Arp, D. J., Berube, P. M., Chain, P. S. G., Hauser, L., Jetten, M. S. M., et al. (2007). Whole-genome analysis of the ammonia-oxidizing 
bacterium, Nitrosomonas eutropha C91: implications for niche adaptation. Environ. Microbiol. 9, 2993-3007. doi: 10.1111/j.1462-2920.2007.01409.x

Stein, L. Y., Campbell, M. A., and Klotz, M. G. (2013). Energy-mediated vs. Ammonium-regulated gene expression in the obligate ammonia oxidizing bacterium, Nitrosococcus oceani. Front. Microbiol. 4:277. doi: 10.3389/fmicb. 2013.00277

Suwa, Y., Imamura, Y., Suzuki, T., Tashiro, T., and Urushigawa, Y. (1994). Ammonia-oxidizing bacteria with different sensitive to (NH4)2SO4 in activated sludges. Water Res. 28, 1523-1532. doi: 10.1016/0043-1354(94) 90218-6

Suwa, Y., Norton, J. M., Bollmann, A., Klotz, M. G., Stein, L. Y., Laanbroek, H. J., et al. (2011). Genome sequence of Nitrosomonas sp. strain AL212, an ammonia-oxidizing bacterium sensitive to high levels of ammonia. J. Bacteriol. 193, 5047-5048. doi: 10.1128/JB.05521-11

Suwa, Y., Sumino, T., and Noto, K. (1997). Phylogenetic relationships of activated sludge isolates of ammonia oxidizers with different sensitivities to ammonium sulfate. J. Gen. Appl. Microbiol. 43, 373-379. doi: 10.2323/jgam.43.373

Tan, N. C. G., Kampschreur, M. J., Wanders, W., van der Pol, W. L. J., van de Vossenberg, J., Kleerebezem, R., et al. (2008). Physiological and phylogenetic study of an ammonium-oxidizing culture at high nitrite concentrations. Syst. Appl. Microbiol. 31, 114-125. doi: 10.1016/j.syapm.2008.01.002

Tokuyama, T., Yoshida, N., Matsuishi, T., Takahashi, N., Takahashi, R., Kanehira, T., et al. (1997). A new psychrotrophic ammonia-oxidizing bacterium, Nitrosovibrio sp. TYM9. J. Ferment. Bioeng. 83, 377-380. doi: 10. 1016/s0922-338x(97)80145-6

Tsuneda, S., Nagano, T., Hoshino, T., Ejiri, Y., Noda, N., and Hirata, A. (2003). Characterization of nitrifying granules produced in an aerobic upflow fluidized bed reactor. Water Res. 37, 4965-4973. doi: 10.1016/j.watres.2003.08.017
Vallenet, D., Belda, E., Calteau, A., Cruveiller, S., Engelen, S., Lajus, A., et al. (2013). MicroScope-an integrated microbial resource for the curation and comparative analysis of genomic and metabolic data. Nucleic Acids Res. 41, E636-E647. doi: 10.1093/nar/gks1194

van Kessel, M. A. H. J., Speth, D. R., Albertsen, M., Nielsen, P. H., Op den Camp, H. J. M., Kartal, B., et al. (2015). Complete nitrification by a single microorganism. Nature 528, 555-559. doi: 10.1038/nature16459

Wells, G. F., Park, H.-D., Yeung, C.-H., Eggleston, B., Francis, C. A., and Criddle, C. S. (2009). Ammonia-oxidizing communities in a highly aerated full-scale activated sludge bioreactor: betaproteobacterial dynamics and low relative abundance of Crenarchaea. Environ. Microbiol. 11, 2310-2328. doi: 10.1111/j. 1462-2920.2009.01958.x

Zhang, Y., Chen, L., Sun, R., Dai, T., Tian, J., and Wen, D. (2015). Ammoniaoxidizing bacteria and archaea in wastewater treatment plant sludge and nearby coastal sediment in an industrial area in China. Appl. Microbiol. Biotechnol. 99, 4495-4507. doi: 10.1007/s00253-014-6352-9

Conflict of Interest Statement: The authors declare that the research was conducted in the absence of any commercial or financial relationships that could be construed as a potential conflict of interest.

Copyright (c) 2016 Thandar, Ushiki, Fujitani, Sekiguchi and Tsuneda. This is an open-access article distributed under the terms of the Creative Commons Attribution License (CC BY). The use, distribution or reproduction in other forums is permitted, provided the original author(s) or licensor are credited and that the original publication in this journal is cited, in accordance with accepted academic practice. No use, distribution or reproduction is permitted which does not comply with these terms. 